\title{
Synthesis of $13(R)-$
}

\section{Hydroxy-7Z,10Z,13R,14E,16Z,19Z}

Docosapentaenoic Acid (13R-HDPA) and Its

Biosynthetic Conversion to the 13-Series Resolvins

\section{Citation}

Primdahl, Karoline G., Marius Aursnes, Mary E. Walker, Romain A. Colas, Charles N. Serhan, Jesmond Dalli, Trond V. Hansen, and Anders Vik. 2016. "Synthesis of 13(R)Hydroxy-7Z, 10Z,13R, 14E, 16Z,19Z Docosapentaenoic Acid (13R-HDPA) and Its Biosynthetic Conversion to the 13-Series Resolvins." Journal of Natural Products 79 (10): 2693-2702. doi:10.1021/acs.jnatprod.6b00634. http://dx.doi.org/10.1021/acs.jnatprod.6b00634.

\section{Published Version}

doi:10.1021/acs.jnatprod.6b00634

\section{Permanent link}

http://nrs.harvard.edu/urn-3:HUL.InstRepos:29738931

\section{Terms of Use}

This article was downloaded from Harvard University's DASH repository, and is made available under the terms and conditions applicable to Other Posted Material, as set forth at http:// nrs.harvard.edu/urn-3:HUL.InstRepos:dash.current.terms-of-use\#LAA

\section{Share Your Story}

The Harvard community has made this article openly available.

Please share how this access benefits you. Submit a story.

\section{Accessibility}




\title{
Synthesis of $13(R)$-Hydroxy-7Z,10Z,13R,14E,16Z,19Z Docosapentaenoic Acid (13R-HDPA) and Its Biosynthetic Conversion to the 13-Series Resolvins
}

\author{
Karoline G. Primdahl, ${ }^{\dagger,}, \S$ Marius Aursnes, ${ }^{\dagger}$ Mary E. Walker, ${ }^{\ddagger}$ Romain A. Colas, ${ }^{\ddagger}$ Charles N. Serhan, ${ }^{\perp}$
} Jesmond Dalli, ${ }^{*}+$ Trond V. Hansen, ${ }^{* \dagger}$ and Anders Vik ${ }^{*} \dagger$

${ }^{\dagger}$ School of Pharmacy, Department of Pharmaceutical Chemistry, University of Oslo, P.O. Box 1068 Blindern, N-0316 Oslo, Norway

${ }^{\star}$ William Harvey Research Institute, Barts and The London School of Medicine and Dentistry, Queen Mary University of London, Charterhouse Square, London, UK, EC1M 6BQ

${ }^{\perp}$ Center for Experimental Therapeutics and Reperfusion Injury, Department of Anesthesiology, Perioperative and Pain Medicine, Harvard Institutes of Medicine, Brigham and Women's Hospital and Harvard Medical School, Boston, Massachusetts 02115, United States

Supporting Information

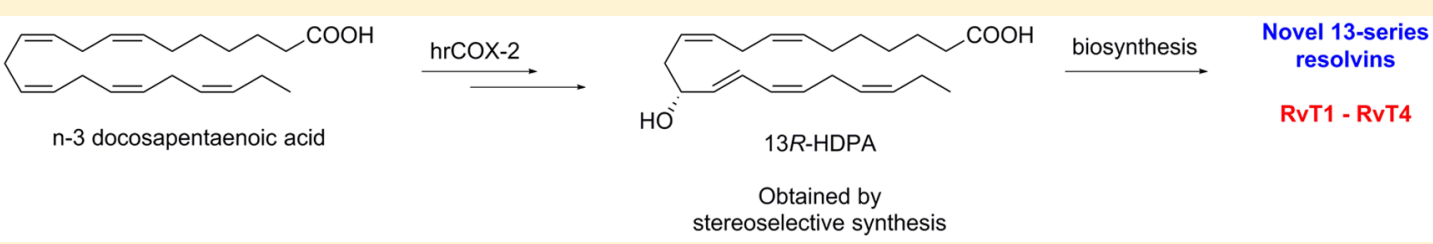

ABSTRACT: Specialized pro-resolving lipid mediators are biosynthesized during the resolution phase of acute inflammation from n-3 polyunsaturated fatty acids. Recently, the isolation and identification of the four novel mediators denoted 13-series resolvins, namely, RvT1 (1), RvT2 (2), RvT3 (3) and RvT4 (4), were reported, which showed potent bioactions characteristic for specialized pro-resolving lipid mediators. Herein, based on results from LC/MS-MS metabololipidomics and the stereoselective synthesis of $13(R)$-hydroxy-7Z,10Z,13R,14E,16Z,19Z docosapentaenoic acid (13R-HDPA, 5), we provide direct evidence that the four novel mediators 1-4 are all biosynthesized from the pivotal intermediate 5. The UV and LC/MS-MS results from synthetic 13R-HDPA (5) matched those from endogenously and biosynthetically produced material obtained from in vivo infectious exudates, endothelial cells, and human recombinant COX-2 enzyme. Stereochemically pure 5 was obtained with the use of a chiral pool starting material that installed the configuration at the C-13 atom as $R$. Two stereoselective Z-Wittig reactions and two $Z$-selective reductions of internal alkynes afforded the geometrically pure alkene moieties in $\mathbf{5}$. Incubation of $\mathbf{5}$ with isolated human neutrophils gave all four RvTs. The results presented herein provide new knowledge on the biosynthetic pathways and the enzymatic origin of RvTs 1-4.

$\mathrm{D}$ uring the resolution of acute inflammation, a novel group of host-protective chemical mediators biosynthesized from the n-3 polyunsaturated fatty acids (PUFAs) eicosapentaenoic acid (EPA) and docosahexaenoic acid (DHA), termed specialized pro-resolving mediators $(\mathrm{SPMs})^{1}$ and their bioactive peptide-conjugates, ${ }^{2}$ are resolution mediators and control tissue regeneration and promote the return to homeostasis. ${ }^{3,4}$ The resolvins, protectins, and maresins constitute individual families of SPMs that are formed via distinct biosynthetic pathways. ${ }^{4}$ During the resolution of acute inflammation, SPMs exhibit a wide range of potent pro-resolving actions, which include promoting the clearance of bacteria and apoptotic cells, counter-regulating the production and actions of proinflammatory mediators, and stimulating the resolution of inflammation. ${ }^{5}$ The PUFA n-3 docosapentaenoic acid (n-3 DPA) is an intermediate in the biosynthesis of DHA from EPA and is also a precursor to novel bioactive mediators. ${ }^{6-8}$ The isolation and structure elucidation of four new host-protective molecules was recently reported. These compounds were termed 13-series resolvins (RvTs), namely, RvT1 (1), RvT2 (2), RvT3 (3) and RvT4 (4), given that they share a hydroxy functionality at carbon $13 .^{8}$

These four enzymatically oxygenated products are biosynthesized during neutrophil-endothelial cocultures and are present, after sterile inflammation as well as infection, in both human and mouse tissues. These four new natural products are biosynthesized from n-3 DPA during neutrophil-endothelial interactions where endothelial cyclooxygenase-2 (COX-2) converts n-3 docosapentaenoic acid to 13-hydro(peroxy)$7 Z, 10 Z, 13,14 E, 16 Z, 19 Z$ docosapentaenoic acid that is then thought to react rapidly, via COX-2-mediated peroxidase activity, into $13(R)$-hydroxy-7Z,10Z,13R,14E,16Z,19Z docosapentaenoic acid (Scheme 1). ${ }^{8}$ The RvTs contain conjugated diene and triene moieties, as well as isolated $Z$-olefins, in

Received: July 8, 2016

Published: October 5, 2016 
<smiles>[R17][R17]</smiles><smiles>[R12]CCCCCC(O)/C=C\C=C/C(O)C(O)/C=C\C=C/C/C=C\CC</smiles><smiles>[R16]CCCCCC(O)CC/C=C\C=C/CC(O)/C=C\C=C/C/C=C\CCCCC(=O)O</smiles>

Scheme 1. Chemical Structure of 13R-HDPA (5) and Outline of Its Proposed Biosynthesis from n-3 DPA

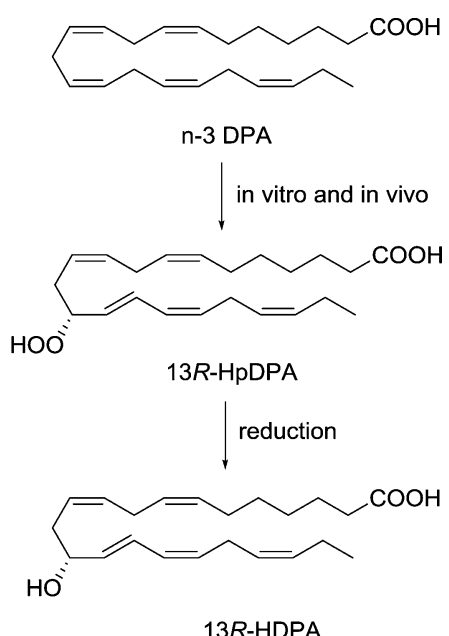

addition to the common hydroxy functionality at C-13. The RvT family of mediators demonstrated potent protective actions increasing mice survival during Escherichia coli (E. coli) infections, and regulate human and mouse phagocyte responses that result in increased bacterial phagocytosis and regulation of inflammasome components. ${ }^{8}$

The presence of a secondary alcohol functionality at C-13 in all four RvTs caught our attention as a common and important chemical feature that most likely is involved early in the biosynthesis of all four RvTs. LC/MS-MS-based experiments using lipid mediator metabololipidomics with materials obtained from human neutrophil-endothelial cell interactions allowed for the identification of a 13-hydroxylated C22compound biosynthesized in human endothelial cell assays. Incubations of n-3 DPA with human recombinant cyclooxygenase-2 (hrCOX-2), together with UV experiments and chiral-phase LC-MS/MS analyses, provided evidence for the involvement of the hydroperoxide of a 13(R)-hydroxydocosapentaenoic acid intermediate (13R-HpDPA) in the biosynthesis of the 13 series resolvins. ${ }^{8}$ Given the potency of these molecules $(\mathrm{pM}-\mathrm{nM})$ and the fact that they are produced in small amounts (pg-ng) within biological systems, it was not possible to determine the exact configurations of the double bonds or the absolute configurations of the secondary alcohols in RvTs 1-4. Based on biosynthetic considerations, ${ }^{4,5,9}$ we tentatively assigned the configurations of the double bonds as depicted.
As bacterial infections in humans remain a serious health concern due to the rise in antibiotic resistance toward existing antibacterial therapeutics, an imminent need for new treatment strategies exists. ${ }^{10}$ Of interest toward this aim, the RvTs 1-4 exert anti-inflammatory and potent pro-resolving activities by regulating key innate protective responses during $E$. coli infections in mice. ${ }^{8}$ Due to the interesting and potent biological activities of the RvTs $\mathbf{1 - 4}$, it is of considerable interest to further investigate their biosynthetic pathways. Herein, we present direct evidence for the configurational assignment of the key biosynthetic intermediate in the RvT pathway, namely, 13R-HDPA (5), by matching material obtained from total synthesis with that isolated from (a) human endothelial cells, (b) mouse infectious exudates, and (c) human recombinant COX-2. We also demonstrate that 13R-HDPA is converted by human neutrophils to all four RvTs, thereby confirming the role of $13 R-H D P A$ as a key biosynthetic intermediate in RvT formation.

\section{RESULTS AND DISCUSSION}

To establish evidence of the existence of 13R-HDPA (5) as a pivotal intermediate and its role in the biosynthesis of the novel 13-series resolvins ( $\operatorname{RvT} 1-4)$, stereochemically pure 5 was obtained by total synthesis. First, a synthesis of the terminal alkyne $\mathbf{1 0}$ from commercially available 2-pentyn-1-ol (6), Scheme 2, was needed. The preparation of diyne 8 was

Scheme 2. Synthesis of (Z)-Hept-4-en-1-yne (10)
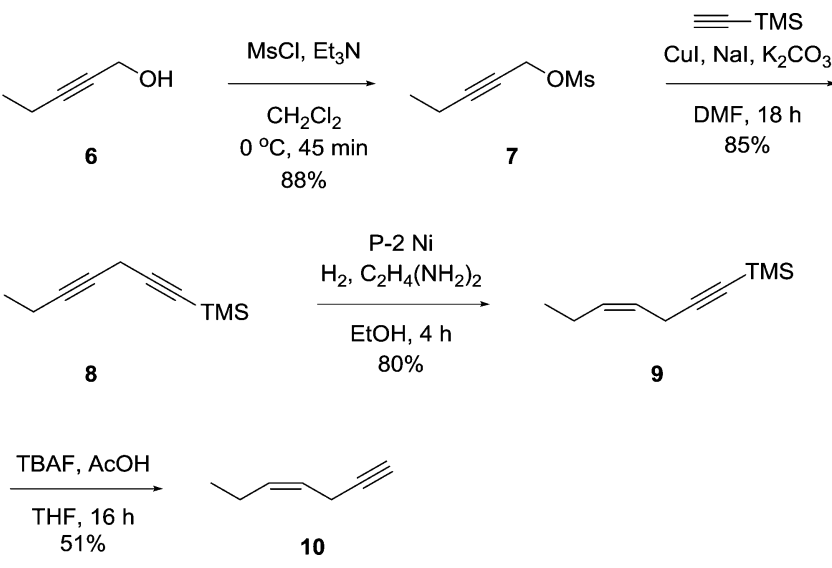

performed as previously reported. ${ }^{11}$ Unfortunately, attempted Lindlar reduction of the internal alkyne in $\mathbf{8}$ gave no conversion to wanted 9. However, the stereoselective $Z$-reduction of the internal alkyne was successfully achieved with P-2 nickel boride $(\mathrm{P}-2 \mathrm{Ni}),{ }^{12,13}$ which provided 9 in $80 \%$ yield. Removal of the TMS-protecting group was achieved using TBAF buffered with acetic acid. Addition of acetic acid was absolutely necessary to suppress the formation of the E-isomer of 10. The modest overall yield of $\mathbf{1 0}$ by this sequence is attributed to the high volatility of $\mathbf{1 0 .}$

Next, vinyl iodide 13 was prepared from commercially available (R)- $\alpha$-hydroxy- $\gamma$-butyrolactone (11), via known alcohol 12. ${ }^{14}$ An alkyne hydrozirconation of 12 , followed by treatment with iodine, furnished the vinyl iodide 13 in fair yield (Scheme 3).

The Wittig salt 19 was prepared from cycloheptanone (14) in eight steps. Phosphonium salt $\mathbf{1 5}$ was obtained as previously reported ${ }^{7}$ in a sequence involving a Baeyer-Villager oxidation of 14, subsequent methanolysis of the resulting lactone, 
Scheme 3. Synthesis of Vinyl Iodide 13

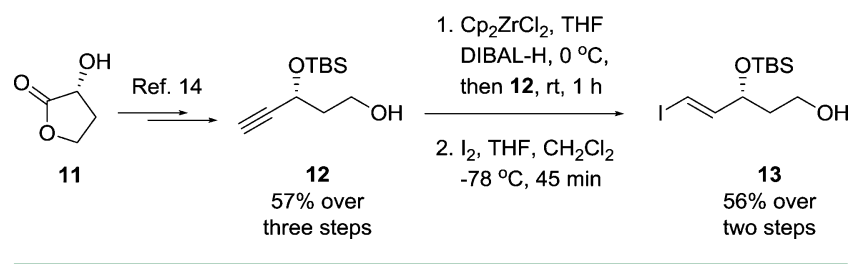

conversion of the formed primary alcohol to its iodide that was reacted with triphenylphospine to give 15 . A Wittig reaction of 15 with TBS-protected 3-hydroxypropanal (16) and subsequent removal of the silyl group ${ }^{15}$ afforded the alcohol 17. This was then converted into the corresponding iodide 18 via an Appel reaction, followed by treatment with triphenylphospine in refluxing acetonitrile that afforded the desired Wittig salt 19 in $81 \%$ yield over the two steps (Scheme 4 ).

\section{Scheme 4. Synthesis of Wittig Salt 19}

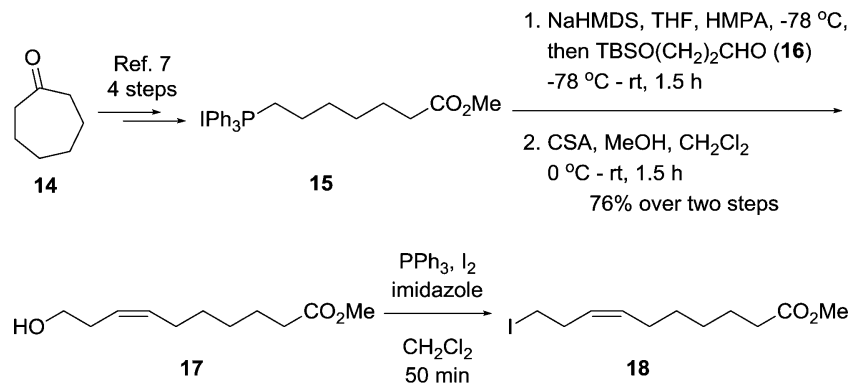

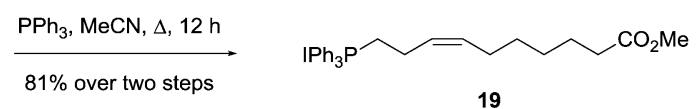

Then terminal alkyne 10 and vinyl iodide 13 were assembled in a Sonogashira cross-coupling reaction, which produced the conjugated enyne 20 in $86 \%$ yield. Oxidation of the alcohol in 20 gave aldehyde $\mathbf{2 1}$, which was immediately reacted in a $Z$ selective Wittig reaction with the ylide of Wittig salt 19; the latter was generated at $-78{ }^{\circ} \mathrm{C}$ after treatment with NaHMDS. This afforded the ester 22 in $77 \%$ yield. Finally, after removal of the silyl group with in situ-generated $\mathrm{HCl}$ from $\mathrm{AcCl}$ in $\mathrm{MeOH}$, the internal alkyne in $\mathbf{2 3}$ was stereoselectively reduced using the Boland protocol, ${ }^{16}$ furnishing the conjugated E,Z-diene $\mathbf{2 4}$ in $67 \%$ yield (Scheme 5 ). The chemical purity of ester 24 was $>98 \%$. Saponification with $\mathrm{LiOH}^{17}$ afforded chemically (>98\%) and stereochemically pure 13R-HDPA (5) (>99\% ee) according to LC-MS/MS analyses using a chiral-phase column (Figure 1).

We next tested whether synthetic 5 matched authentic $13 R$ HDPA (5). We first isolated material from human umbilical endothelial cells ${ }^{8}$ that in RP-HPLC-MS-MS metabololipidomics ${ }^{18}$ gave a sharp peak with retention time $\left(R_{\mathrm{T}}\right)$ of $17.5 \mathrm{~min}$ (Figure 1A). 13-HDPA from infectious exudates and from hrCOX-2 also eluted with $R_{\mathrm{T}} 17.5 \mathrm{~min}$ (Figure 1B,C). The same retention time was observed $\left(R_{\mathrm{T}}=17.5 \mathrm{~min}\right)$ for synthetic 13R-HDPA (5), Figure 1D. Moreover, coinjection of biological 13-HPDA with synthetic material of 5 gave a single sharp peak with $R_{\mathrm{T}} 17.5 \mathrm{~min}$ (Figure $1 \mathrm{E}$ ).

Then we sought evidence for the absolute configuration at $\mathrm{C}$ 13 and that synthetic material of 5 eluted with biological $13 R$ HDPA in a chiral environment. In all biological systems tested,
Scheme 5. Synthesis of 13R-HDPA (5)
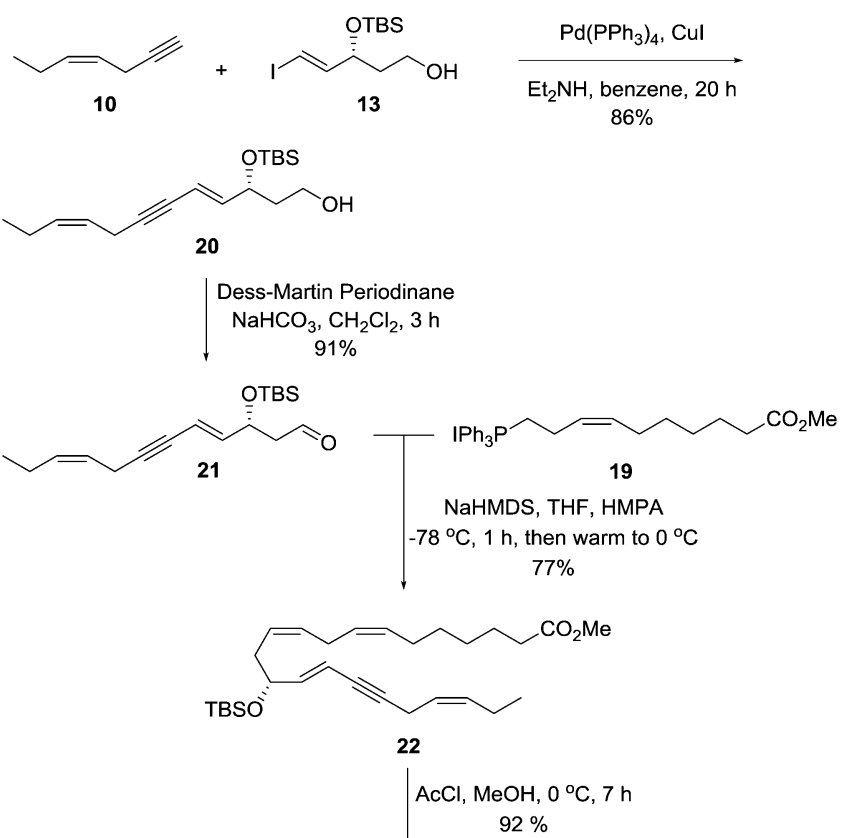

$92 \%$

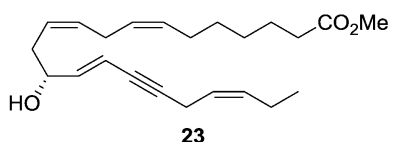

23

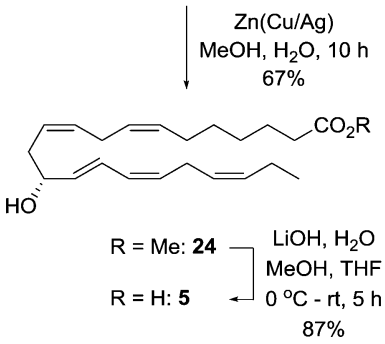

13R-HDPA was the main product giving a sharp peak at $R_{\mathrm{T}} 5.1$ min in a chiral-phase chromatography-tandem mass spectrometry system (Figures 2A-C). Synthetic 13R-HDPA (5) also gave $R_{\mathrm{T}} 5.1 \mathrm{~min}$ (Figure $2 \mathrm{D}$ ), and when this material was coinjected with biological material, a sharp peak only at $R_{\mathrm{T}} 5.1$ min was observed (Figure 2E). Of note, in the endothelial cell and recombinant enzyme incubations, we also identified the $S$ isomer of 13-HDPA that was found to be the minor product in both incubations forming $\sim 10 \%$ of the overall 13-HDPA levels in the HUVEC incubations (Figure $2 \mathrm{~A}$ ) and $<5 \%$ in the recombinant enzyme incubations (Figure 2C). This is in accordance with published findings that COX-2 stereoselectively converts n-3 DPA to the R-configured stereoisomer with a small proportion of the substrate being converted to the $S$-stereoisomer. ${ }^{8}$ This is also observed for other enzymes that lipoxygenate their substrate. ${ }^{19}$ Altogether, these efforts established that the synthetic material of $\mathbf{5}$ eluted together with biologically produced 13-HDPA and that the absolute configuration at C-13 is $R$ for biogenic 13-HDPA (5).

To obtain further evidence for matching physical properties of authentic and synthetic material of 5, MS-MS spectra for 13R-HDPA from HUVEC incubations, infectious exudates and synthetic material of $\mathbf{5}$ were recorded, that gave essentially identical MS-MS spectra including fragments at $\mathrm{m} / z$ 327, 301, 283, 223, 205, and 195 (Figure 3A-C). 

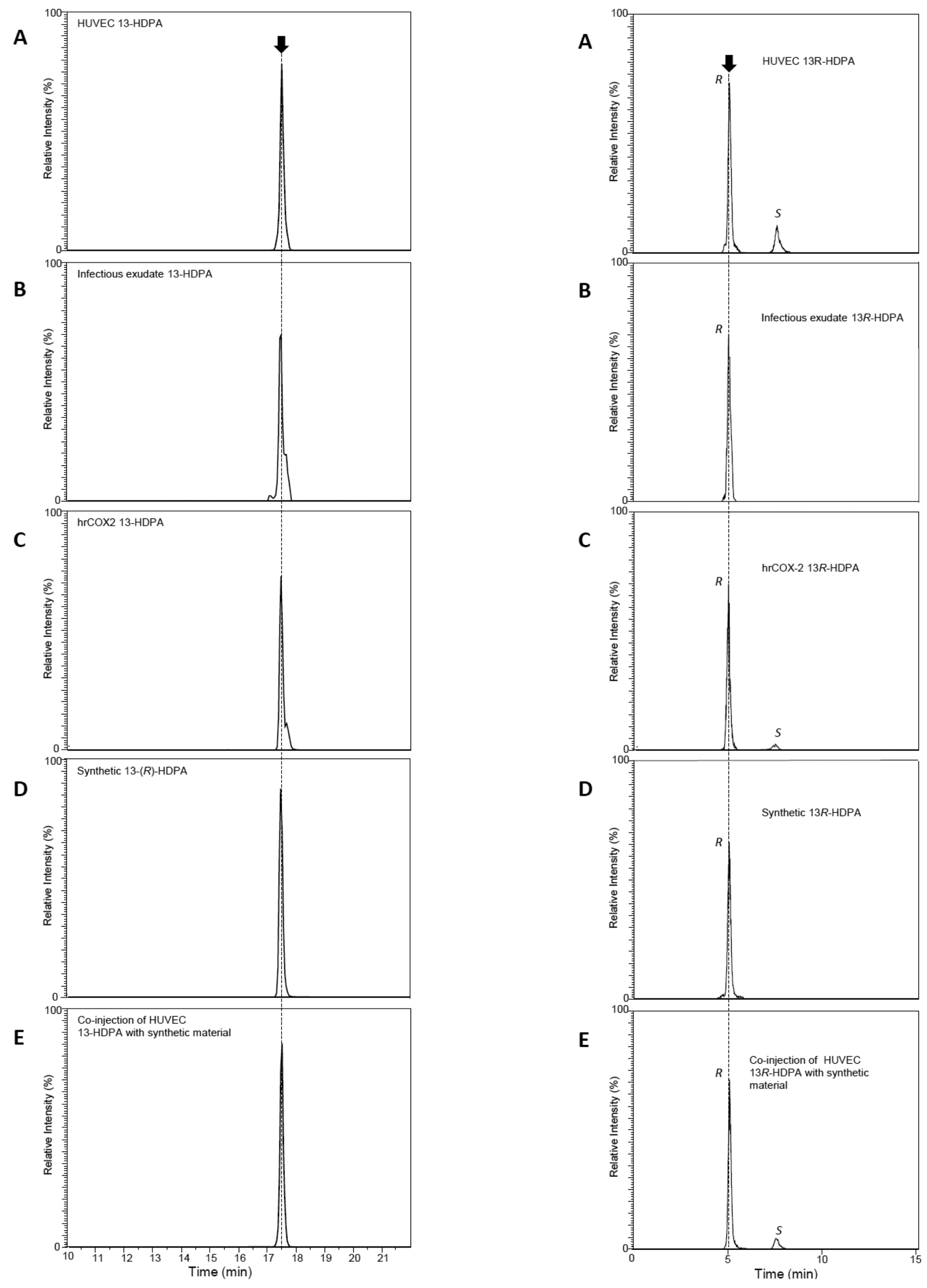

Figure 1. 13-HDPA MRM chromatograms from (A) endothelial cells, (B) infectious exudates, (C) hrCOX-2, and (D) synthetic material of 5. (E) Coinjection of endothelial and synthetic 5.
Figure 2. 13-HDPA chiral LC-MS-MS derived from (A) endothelial cells, (B) infectious exudates, (C) hrCOX-2, and (D) synthetic material. (E) Coinjection of endothelial and synthetic 13R-HDPA. 
A

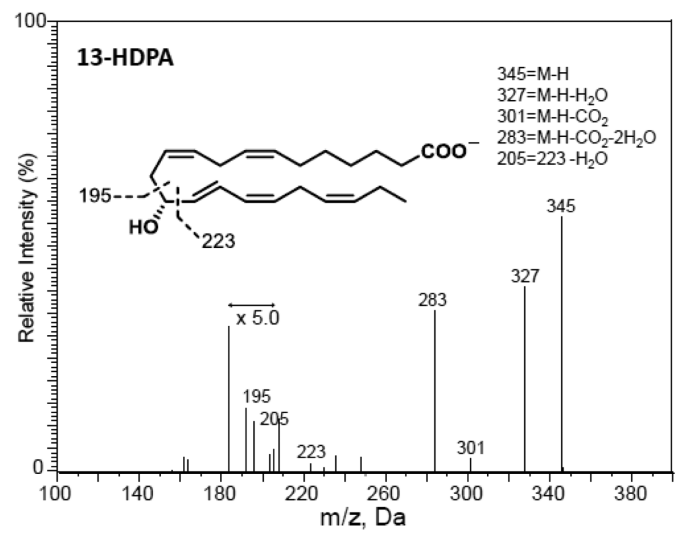

B

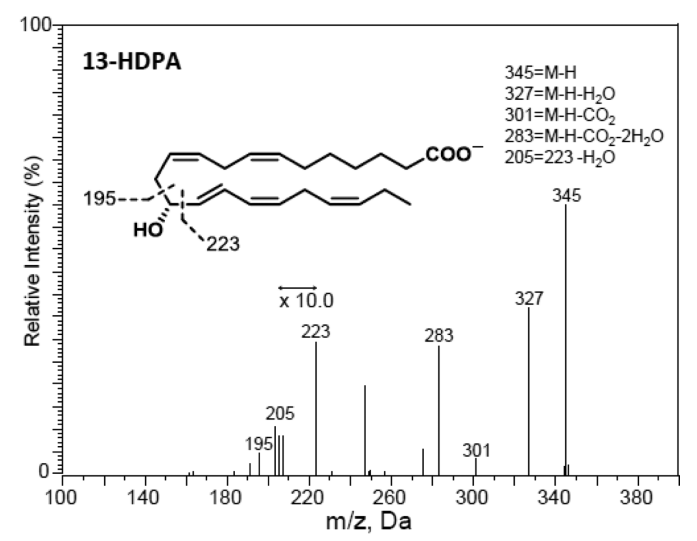

C

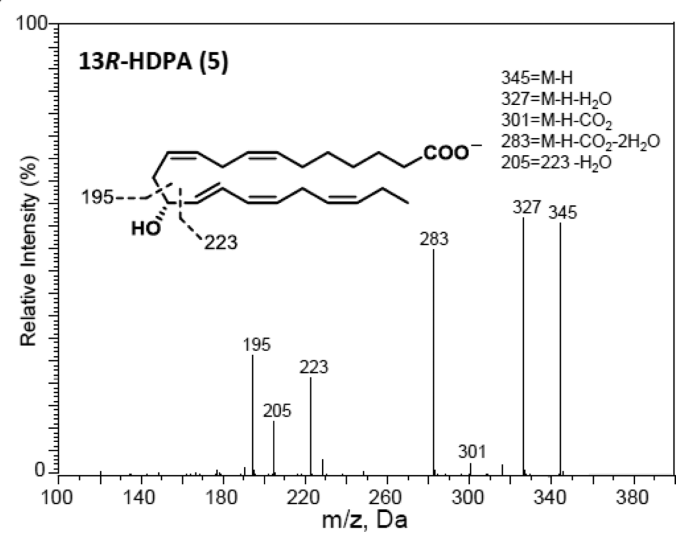

Figure 3. MS-MS spectra employed in the identification of 13-HDPA from (A) endothelial cells, (B) infectious exudates, and (C) synthetic material. $n=3$ endothelial cell donors, $n=3$ mouse exudates, and $n=$ 3 for synthetic material.

Assessment of the UV chromophore of biogenic 13R-HDPA from hrCOX-2 and that of the synthetic material of $\mathbf{5}$, both gave $\lambda_{\max }^{\mathrm{MeOH}}$ of $237 \mathrm{~nm}$ (Figure $4 \mathrm{~A}, \mathrm{~B}$ ), adding additional confidence in our structural assignment.

We next tested whether the synthetic material 5 was a substrate for the conversion to any of the four RvTs by human neutrophils. Incubation of synthetic 13R-HDPA (5) with human neutrophils gave RvT1 (1), RvT2 (2), RvT3 (3), and RvT4 (4), as determined using both retention time (Figure 5A) and MS-MS spectra (Figure 5B). Of note in incubations with neutrophils without 13R-HDPA (5), levels of RvT1 (1), RvT2 (2), RvT3 (3), and RvT4 (4), were $>75 \%$ lower than those found in incubations with the synthetic material. These results are in accordance with published findings ${ }^{8}$ and indicate that while PMN may utilize endogenous $13 R$-HDPA, which may be esterified and released upon cellular activation as observed for other SPM biosynthetic intermediates, ${ }^{20}$ these cells rely on other cell types to donate this key biosynthetic intermediate for RvT biosynthesis. Together these results establish the exact structural assignment of 13R-HDPA as 13(R)-hydroxy$7 Z, 10 Z, 13 R, 14 E, 16 Z, 19 Z$ docosapentaenoic acid (5), as well as its key role in the RvT biosynthetic pathway.

\section{CONCLUSIONS}

The biosynthesis of SPMs in human physiological systems affords the $\mathrm{E}$ - and $\mathrm{D}$-series resolvins with either a $E, E, Z, E-$ tetraene or a $E, E, Z$-triene moiety. ${ }^{2,4}$ On the other hand, the $13 R$-series-resolvins display diene and triene moieties, isolated $Z$-olefins, and a hydroxy functionality at C-13. These features distinguish the $13 R$-series-resolvins from the established families of SPMs (i.e., the resolvins, protectins, and maresins), as well as other oxygenated natural products of nonhuman origin. ${ }^{21}$ Herein, we have demonstrated that the COX-2 enzyme is involved in the first step in the biosynthetic pathways of the 13R-series-resolvins. Most likely, as for the other SPM families, ${ }^{5}$ the first step involves the formation of a hydroperoxide intermediate that undergoes distinct enzymatic multistep sequences to the individual natural products 1-4. Because all families of SPMs, ${ }^{22}$ as well as other oxygenated PUFA-derivatives, ${ }^{21,23}$ exhibit potent and interesting pharmacological actions, these natural products are of interest as lead compounds toward the clinical development of different treatments for human diseases, via a novel mechanism as resolution agonists. Such efforts will be more expedient with knowledge of the complete structural assignment and biosynthetic pathways of SPMs such as the 13R-series resolvins.

\section{EXPERIMENTAL SECTION}

General Experimental Procedures. Optical rotations were measured using a $0.7 \mathrm{~mL}$ cell with a $1.0 \mathrm{dm}$ path length on an Anton Paar MCP 100 polarimeter. The UV-vis spectra from 190 to $900 \mathrm{~nm}$ were recorded on a Shimadzu UV-1800 spectrophotometer using quartz cuvettes. NMR spectra were recorded on a Bruker AVII400 spectrometer at $400 \mathrm{MHz}$ or a Bruker AVII600 spectrometer at $600 \mathrm{MHz}$ for ${ }^{1} \mathrm{H} \mathrm{NMR}$, and at 100 or $150 \mathrm{MHz}$ for ${ }^{13} \mathrm{C} \mathrm{NMR}$. Spectra are referenced relative to the central residual protium solvent resonance in ${ }^{1} \mathrm{H} \mathrm{NMR}\left(\mathrm{CDCl}_{3} \delta_{\mathrm{H}}=7.27\right.$, and $\left.\mathrm{MeOH}-d_{4} \delta_{\mathrm{H}}=3.31\right)$ and the central carbon solvent resonance in ${ }^{13} \mathrm{C} \mathrm{NMR}\left(\mathrm{CDCl}_{3} \delta_{\mathrm{C}}=\right.$ $77.00 \mathrm{ppm}$, and $\left.\mathrm{MeOH}-d_{4}=\delta_{\mathrm{C}}=49.00\right)$. High-resolution mass spectra were recorded on a Waters Prospec Q spectrometer using ES as the method of ionization. Thin-layer chromatography was performed on silica gel 60 F254 aluminum-backed plates fabricated by Merck. Flash column chromatography was performed on silica gel $60(40-63 \mu \mathrm{m})$ produced by Merck. HPLC analyses for chemical purities were performed on an Agilent Technologies 1200 Series instrument with diode array detector set at $254 \mathrm{~nm}$ and equipped with a C18 stationary phase (Eclipse XDB-C18 $5 \mu \mathrm{m} 4.6 \times 150 \mathrm{~mm}$ ), applying the conditions stated. GLC-analyses were performed on an Agilent Technologies 7820A GC instrument with split injection, FID detector and equipped with an Agilent J\&W HP-5 GC column $(30 \mathrm{~m} \times 0.32$ $\mathrm{mm}, 0.25 \mu \mathrm{m}$ ) applying the conditions stated. Unless stated otherwise, all commercially available reagents and solvents were used in the form they were supplied without any further purification. All reactions were performed under an argon atmosphere, unless otherwise stated. The stated yields are based on isolated material. Liquid chromatography (LC)-grade solvents were purchased from Fisher Scientific. The Eclipse Plus C18 column $(100 \times 4.6 \mathrm{~mm} \times 1.8 \mu \mathrm{m})$ was obtained from Agilent and C18 SPE columns were from Waters. Commercially available lipid mediators were obtained from Cayman Chemical. 

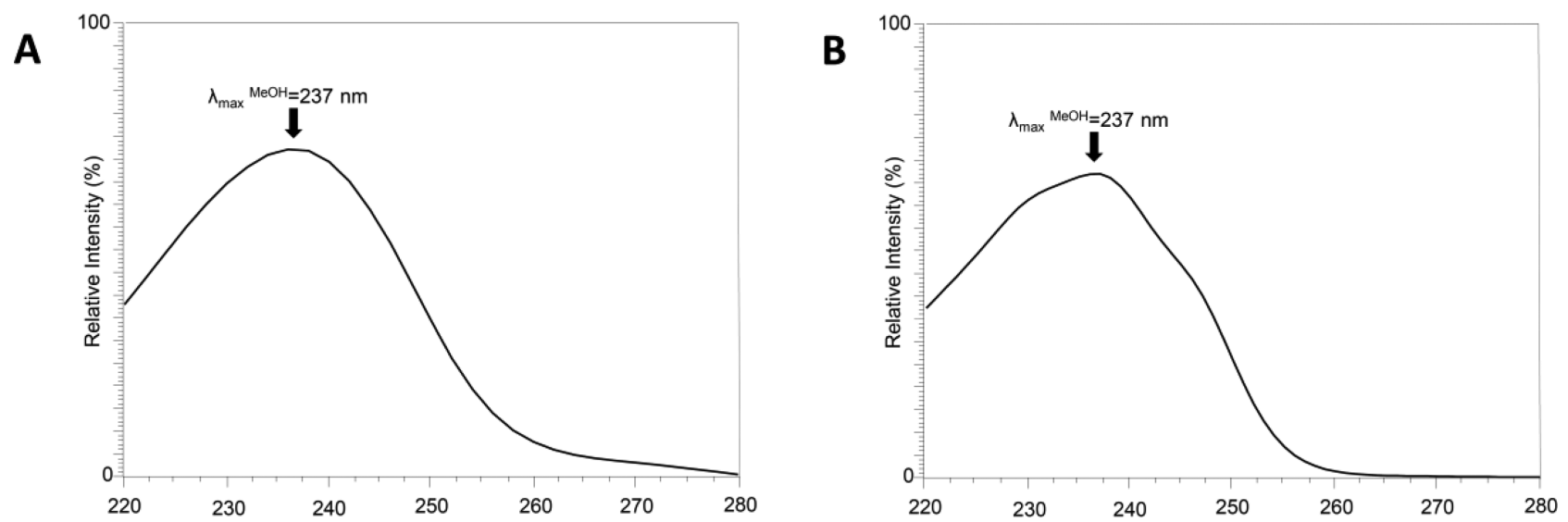

Figure 4. UV spectra for (A) hrCOX-2 13-HDPA and (B) synthetic 13R-HDPA (5).

A
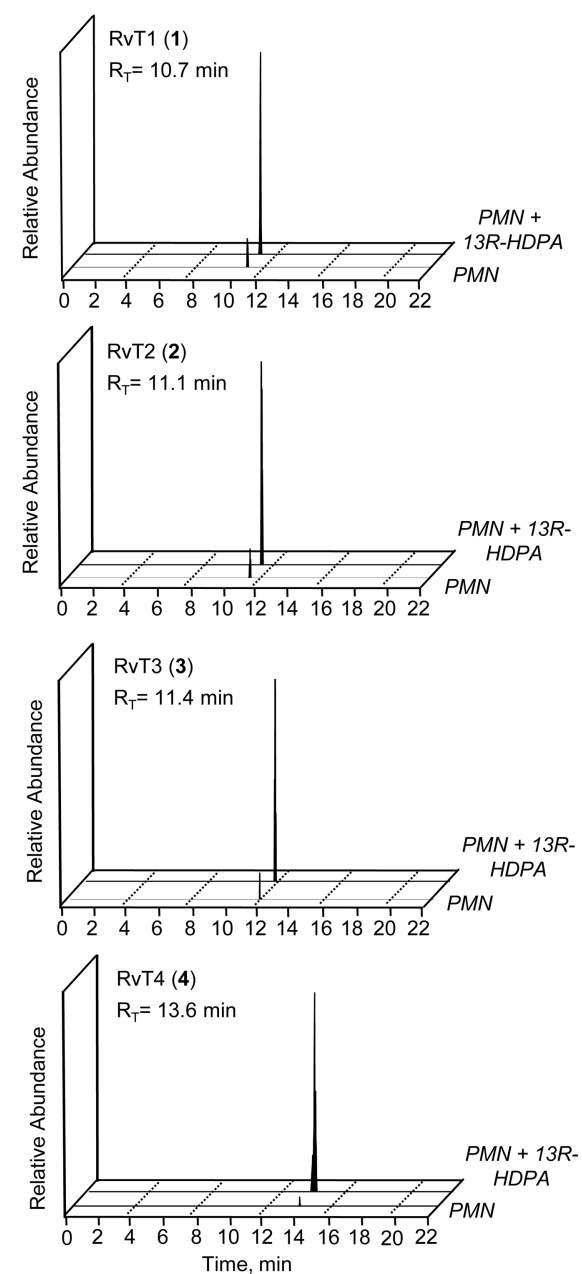
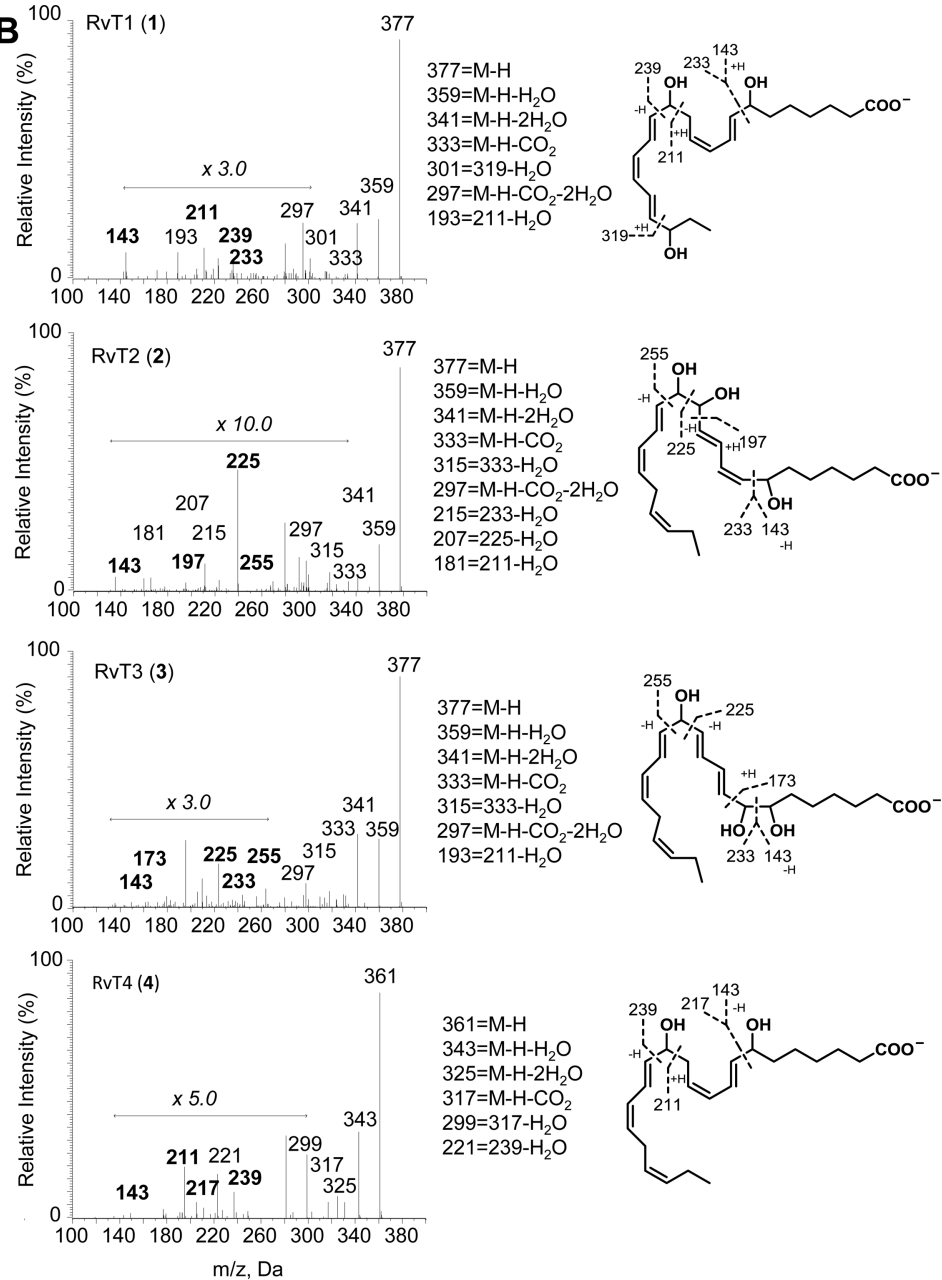
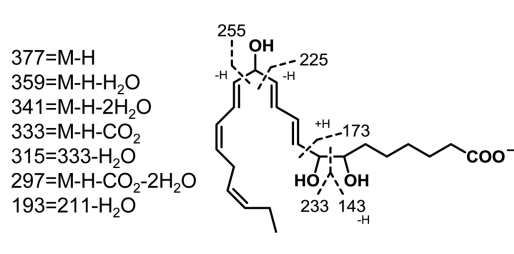

$361=\mathrm{M}-\mathrm{H}$ $343=\mathrm{M}-\mathrm{H}-\mathrm{H}_{2} \mathrm{O}$ $325=\mathrm{M}-\mathrm{H}-2 \mathrm{H}_{2} \mathrm{O}$ $317=\mathrm{M}-\mathrm{H}-\mathrm{CO}_{2}$ $299=317-\mathrm{H}_{2} \mathrm{O}$ $221=239-\mathrm{H}_{2} \mathrm{O}$

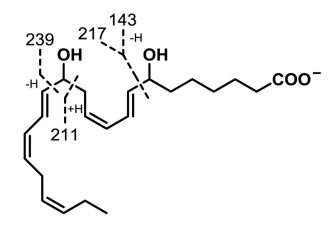

Figure 5. Human neutrophils convert 13R-HDPA (5) to RvT1-4 (1-4). Human neutrophils were isolated from peripheral blood of healthy donors and incubated $\left(2 \times 10^{7}\right.$ cells $\left./ \mathrm{mL}\right)$ with or without $13 R$-HDPA $(5)\left(45 \mathrm{~min}, 37^{\circ} \mathrm{C}, 2 \mu \mathrm{M} \mathrm{A} 23187, \mathrm{PBS}, \mathrm{pH}=7.45\right)$. Incubations were quenched with two volumes of ice cold $\mathrm{MeOH}$ and products extracted and profiled using lipid mediator metabololipidomics. (A) MRM chromatograms for each of the RvT1-4 with relative abundances to their levels in each of the incubations. (B) MS-MS spectra employed in the identification of RvT1 (1), RvT2 (2), RvT3 (3) and RvT4 (4). Results are representative of $n=3$ healthy volunteers.

(Z)-Hept-4-en-1-yn-1-yltrimethylsilane (9). A suspension of sodium borohydride $(32.9 \mathrm{mg}, 0.87 \mathrm{mmol})$ in $\mathrm{EtOH}(1.3 \mathrm{~mL})$ was added dropwise to a flask containing nickel acetate tetrahydrate $(217$ $\mathrm{mg}, 0.87 \mathrm{mmol}, 14 \mathrm{~mol} \%)$ in $\mathrm{EtOH}(13.0 \mathrm{~mL})$ at $0{ }^{\circ} \mathrm{C}$ under stirring. The reaction mixture turned black. After stirring for $15 \mathrm{~min}$ at room temperature, ethylenediamine $(116 \mu \mathrm{L}, 105 \mathrm{mg}, 1.74 \mathrm{mmol})$ was added, and the stirring was continued for $10 \mathrm{~min}$. The flask was evacuated and refilled with hydrogen gas before the skipped diyne $8^{11}$ was added $(1.00 \mathrm{~g}, 6.09 \mathrm{mmol}, 1.00$ equiv). The reaction mixture was stirred at room temperature under hydrogen atmosphere until completion $(\sim 4 \mathrm{~h})$, then filtered through a short plug of silica gel that was washed with pentane $(10 \mathrm{~mL})$. The filtrate was transferred to a separatory funnel and washed with $\mathrm{H}_{2} \mathrm{O}(3 \times 5.0 \mathrm{~mL})$. The organic layer was dried $\left(\mathrm{MgSO}_{4}\right)$, and the solvent was removed in vacuo. 
Purification by flash chromatography on silica gel (pentane) afforded the desired product 9 as a colorless oil. Yield: $810 \mathrm{mg}(80 \%) ;{ }^{1} \mathrm{H}$ NMR $\left(400 \mathrm{MHz}, \mathrm{CDCl}_{3}\right) \delta_{\mathrm{H}} 5.51-5.42(\mathrm{~m}, 1 \mathrm{H}), 5.42-5.35(\mathrm{~m}, 1 \mathrm{H}), 2.98$ $(\mathrm{m}, 2 \mathrm{H}), 2.06(\mathrm{p}, J=7.5 \mathrm{~Hz}, 2 \mathrm{H}), 0.98(\mathrm{t}, J=7.5 \mathrm{~Hz}, 3 \mathrm{H}), 0.15(\mathrm{~s}$, $9 \mathrm{H}) .{ }^{13} \mathrm{C}$ NMR $\left(101 \mathrm{MHz}, \mathrm{CDCl}_{3}\right) \delta_{\mathrm{C}} 133.7,123.4,105.7,84.2,20.7$, $18.4,14.1,0.3$. TLC (hexane, $\mathrm{KMnO}_{4}$ stain) $R_{\mathrm{f}}=0.12$. The spectroscopic data were in agreement with those previously reported for this compound. ${ }^{24}$

(Z)-Hept-4-en-1-yne (10). (Z)-Hept-4-en-1-yn-1-yltrimethylsilane (9) $(700 \mathrm{mg}, 4.21 \mathrm{mmol}, 1.00$ equiv) was added to a solution of TBAF (1.0 $\mathrm{M}$ in THF, $6.74 \mathrm{~mL}, 6.74 \mathrm{mmol}, 1.60$ equiv) and acetic acid ( 0.40 $\mathrm{mL}, 6.95 \mathrm{mmol})$. The reaction was stirred at room temperature for 16 $h$ and quenched with $\mathrm{H}_{2} \mathrm{O}(6.0 \mathrm{~mL})$. Pentane $(40 \mathrm{~mL})$ was added, and the organic layer was washed with saturated aq $\mathrm{NaHCO}_{3}(7.0 \mathrm{~mL})$, water $(10 \times 7.0 \mathrm{~mL})$ to remove the remaining THF, and then dried $\left(\mathrm{MgSO}_{4}\right)$. Pentane was removed by distillation. After distillation, the product still contained traces of solvents, but that was accounted for in the next step. Yield: $189 \mathrm{mg}(47 \%) ;{ }^{1} \mathrm{H}$ NMR $\left(400 \mathrm{MHz}, \mathrm{CDCl}_{3}\right) \delta_{\mathrm{H}}$ 5.53-5.45 (m, 1H), 5.44-5.36 (m, 1H), $2.94(\mathrm{~m}, 2 \mathrm{H}), 2.13-2.00(\mathrm{~m}$, $2 \mathrm{H}), 1.97(\mathrm{t}, J=2.7 \mathrm{~Hz}, 1 \mathrm{H}), 0.99(\mathrm{t}, J=7.5 \mathrm{~Hz}, 3 \mathrm{H}) ;{ }^{13} \mathrm{C}$ NMR $(101$ $\left.\mathrm{MHz}, \mathrm{CDCl}_{3}\right) \delta_{\mathrm{C}} 134.0,123.1,83.2,68.1,20.6,16.9$, 14.0. The spectroscopic data were in agreement with those previously reported for this compound. ${ }^{25}$

(R,E)-3-((tert-Butyldimethylsilyl)oxy)-5-iodopent-4-en-1-ol (13). Compound 12 was prepared as previously reported. ${ }^{14}$ The Schwartz's reagent was prepared in situ following the procedure by Huang and Negishi. ${ }^{26} \mathrm{Cp}_{2} \mathrm{ZrCl}_{2}(1.24 \mathrm{~g}, 4.23 \mathrm{mmol}, 2.10$ equiv) in THF (5.00 $\mathrm{mL}$ ) was cooled to $0{ }^{\circ} \mathrm{C}$ and stirred under argon. A solution of DIBAL-H (1.0 M in THF, $4.23 \mathrm{~mL}, 4.23 \mathrm{mmol})$ was added dropwise. The resultant suspension was stirred for $30 \mathrm{~min}$ at $0{ }^{\circ} \mathrm{C}$ and protected from light with aluminum foil, before the terminal alkyne $12(431 \mathrm{mg}$, $2.02 \mathrm{mmol}, 1.00$ equiv) in THF $(1.00 \mathrm{~mL})$ was added. The cooling bath was removed, and the reaction mixture stirred at room temperature until a homogeneous solution was observed (ca. $1 \mathrm{~h}$ ) and then cooled to $-78^{\circ} \mathrm{C}$. A solution of $\mathrm{I}_{2}(665 \mathrm{mg}, 5.24 \mathrm{mmol}, 1.24$ equiv) in THF/ $\mathrm{CH}_{2} \mathrm{Cl}_{2}(3.00 \mathrm{~mL}, 1: 1)$ was added. The reaction mixture was stirred $45 \mathrm{~min}$ before it was filtered through a plug of silica gel that was successively washed with $20 \%$ EtOAc in heptane. The solvent was removed under reduced pressure, and the crude product was purified by column chromatography on silica gel (heptane/EtOAc $8: 2)$ to afford the vinyl iodine $\mathbf{1 3}$ as a pale yellow oil. Yield: $385 \mathrm{mg}$ $(56 \%) ;[\alpha]_{D}^{20}+58(c=0.29, \mathrm{MeOH}) ;{ }^{1} \mathrm{H}$ NMR $\left(400 \mathrm{MHz}, \mathrm{CDCl}_{3}\right)$ $\delta_{\mathrm{H}} 6.56(\mathrm{dd}, J=14.4,6.0 \mathrm{~Hz}, 1 \mathrm{H}), 6.29(\mathrm{dd}, J=14.4,1.2 \mathrm{~Hz}, 1 \mathrm{H})$, $4.37(\mathrm{~m}, 1 \mathrm{H}), 3.79(\mathrm{ddd}, J=10.9,7.9,4.3 \mathrm{~Hz}, 1 \mathrm{H}), 3.70(\mathrm{~m}, 1 \mathrm{H}), 2.02$ (s, 1H), $1.81(\mathrm{~m}, 1 \mathrm{H}), 1.72(\mathrm{~m}, 1 \mathrm{H}), 0.90(\mathrm{~s}, 9 \mathrm{H}), 0.09(\mathrm{~s}, 3 \mathrm{H}), 0.06$ $(\mathrm{s}, 3 \mathrm{H}) ;{ }^{13} \mathrm{C} \mathrm{NMR}\left(101 \mathrm{MHz}, \mathrm{CDCl}_{3}\right) \delta_{\mathrm{C}} 148.4,76.5,74.3,59.7,39.1$, 25.9 (3C), 18.3, -4.4, -4.9; . HRESITOFMS: $m / z$ 365.0403 [M + $\mathrm{Na}]^{+}$(calcd for $\mathrm{C}_{11} \mathrm{H}_{23} \mathrm{IO}_{2} \mathrm{SiNa}, 365.0410$ ); TLC (hexane/EtOAc 7:3, $\mathrm{KMnO}_{4}$ stain) $R_{\mathrm{f}}=0.37$.

Methyl (Z)-10-hydroxydec-7-enoate (17). The ester 17 was prepared according to a literature procedure. ${ }^{2 \mathrm{c}}$ The known Wittig salt $15^{7}$ (1.70 g, $3.19 \mathrm{mmol}, 1.00$ equiv) was dissolved in THF (42.0 $\mathrm{mL})$ and HMPA $(4.20 \mathrm{~mL})$ and cooled to $-78^{\circ} \mathrm{C}$. NaHMDS $(0.60 \mathrm{M}$ in toluene, $5.30 \mathrm{~mL}, 3.18 \mathrm{mmol}, 1.00$ equiv) was added dropwise, and the reaction mixture was stirred for 30-45 min. Aldehyde $6(631 \mathrm{mg}$, $3.35 \mathrm{mmol}, 1.05$ equiv) in THF $(4.20 \mathrm{~mL})$ was then added dropwise, and stirring was continued for $1.5 \mathrm{~h}$ at $-78{ }^{\circ} \mathrm{C}$. The flask was allowed to slowly warm up to $0{ }^{\circ} \mathrm{C}$, and the reaction was quenched with phosphate buffer $(21.1 \mathrm{~mL}, \mathrm{pH}=7.2)$. The aq phase was extracted with $\mathrm{Et}_{2} \mathrm{O}(2 \times 20.0 \mathrm{~mL})$, and the combined organic layers were dried $\left(\mathrm{Na}_{2} \mathrm{SO}_{4}\right)$ and concentrated in vacuo. The crude material was passed through a short plug of silica that was washed with $5 \%$ EtOAc in heptane $\left(R_{\mathrm{f}}=0.26\right)$. The crude product $(868 \mathrm{mg}, 2.76 \mathrm{mmol}, 1.00$ equiv) was dissolved in $\mathrm{CH}_{2} \mathrm{Cl}_{2} / \mathrm{MeOH}(1: 2,34.0 \mathrm{~mL})$ and cooled to $0{ }^{\circ} \mathrm{C}$. Camphor-10-sulfonic acid (642 mg, $2.76 \mathrm{mmol}, 1.00$ equiv) was added in one portion, and the reaction mixture was stirred for $30 \mathrm{~min}$ at $0{ }^{\circ} \mathrm{C}$ before it was allowed to slowly warm up to room temperature and stirred for $1 \mathrm{~h}$. The reaction was quenched with saturated aq $\mathrm{NaHCO}_{3}(33.3 \mathrm{~mL})$, extracted with $\mathrm{CH}_{2} \mathrm{Cl}_{2}(2 \times 15.0 \mathrm{~mL})$, dried $\left(\mathrm{Na}_{2} \mathrm{SO}_{4}\right)$, and concentrated in vacuo. The crude product was purified by column chromatography on silica gel (heptane/EtOAc 7:3) to afford hydroxyl methyl ester $\mathbf{1 7}$ as a clear oil. The chemical purity (>99\%) was determined by GLC analysis: Initial temperature $100{ }^{\circ} \mathrm{C}$, rate: $5{ }^{\circ} \mathrm{C} / \mathrm{min}$, final temperature $200{ }^{\circ} \mathrm{C}, t_{\mathrm{r}}($ minor $)=8.90 \mathrm{~min}, t_{\mathrm{r}}$ (major) $=9.22 \mathrm{~min}$. Yield: $483 \mathrm{mg}(76 \%) ;{ }^{1} \mathrm{H}$ NMR $(400 \mathrm{MHz}$, $\left.\mathrm{MeOH}-d_{4}\right) \delta_{\mathrm{H}} 7.08-6.90(\mathrm{~m}, 2 \mathrm{H}), 5.21(\mathrm{~s}, 3 \mathrm{H}), 5.09(\mathrm{t}, J=7.0 \mathrm{~Hz}$, $2 \mathrm{H}), 3.92-3.77(\mathrm{~m}, 4 \mathrm{H}), 3.64(\mathrm{q}, J=6.7 \mathrm{~Hz}, 2 \mathrm{H}), 3.18(\mathrm{q}, J=7.3 \mathrm{~Hz}$, $2 \mathrm{H}), 2.93(\mathrm{~m}, 4 \mathrm{H}) .{ }^{13} \mathrm{C}$ NMR $\left(101 \mathrm{MHz}, \mathrm{MeOH}-d_{4}\right) \delta_{\mathrm{C}} 176.0,132.7$, $126.9,62.8,51.9,34.8,31.8,30.4,29.8,28.1,25.9$. HRMS (TOF ES ${ }^{+}$): $\mathrm{m} / z 223.1305[\mathrm{M}+\mathrm{Na}]^{+}$(calcd for $\left.\mathrm{C}_{11} \mathrm{H}_{20} \mathrm{O}_{3} \mathrm{Na}, 223.1310\right)$. TLC (Heptane/EtOAc 7:3, $\mathrm{KMnO}_{4}$ stain): $R_{\mathrm{f}}=0.23$.

Methyl (Z)-10-(iodotriphenyl- $\lambda 5$-phosphanyl)dec-7-enoate (19). Iodide 18 was prepared from hydroxy ester $17(483 \mathrm{mg}, 2.42 \mathrm{mmol}$, 1.00 equiv) according to a procedure reported by Mioskowski and coworkers $^{27}$ and used directly in the next reaction. Iodide 18 (638 g, 2.06 mmol, 1.00 equiv) was dissolved in dry $\mathrm{MeCN}(20.0 \mathrm{~mL})$. Triphenylphosphine ( $1.08 \mathrm{~g}, 4.12 \mathrm{mmol}, 2.00$ equiv) was added, and the reaction mixture was heated to reflux for $12 \mathrm{~h}$. The reaction mixture was concentrated in vacuo. The crude product was purified by column chromatography on silica gel $\left(\mathrm{CH}_{2} \mathrm{Cl}_{2} / \mathrm{MeOH} 95: 5\right)$ to afford the Wittig salt 19 as a clear oil. Yield: $1.12 \mathrm{~g}(81 \%) ;{ }^{1} \mathrm{H}$ NMR (400 $\left.\mathrm{MHz}, \mathrm{MeOH}-d_{4}\right) \delta 8.00-7.64(\mathrm{~m}, 15 \mathrm{H}), 5.56-5.42(\mathrm{~m}, 2 \mathrm{H}), 3.63(\mathrm{~s}$, $3 \mathrm{H}), 3.57-3.45(\mathrm{~m}, 2 \mathrm{H}), 2.49-2.38(\mathrm{~m}, 2 \mathrm{H}), 2.28(\mathrm{t}, J=7.3 \mathrm{~Hz}, 2 \mathrm{H})$, $1.90(\mathrm{q}, J=6.8 \mathrm{~Hz}, 2 \mathrm{H}), 1.52(\mathrm{p}, J=7.4 \mathrm{~Hz}, 2 \mathrm{H}), 1.36-1.19(\mathrm{~m}, 4 \mathrm{H})$. ${ }^{13} \mathrm{C}$ NMR $\left(101 \mathrm{MHz}, \mathrm{MeOH}-d_{4}\right) \delta_{\mathrm{C}} 175.8,136.3\left(\mathrm{~d}, 4^{\prime} J_{\mathrm{CP}}=3.0 \mathrm{~Hz}\right.$, 3C), $134.9\left(\mathrm{~d}, 3^{\prime} J_{\mathrm{CP}}=10.0 \mathrm{~Hz}, 6 \mathrm{C}\right), 133.5,131.6\left(\mathrm{~d}, 2^{\prime} J_{\mathrm{CP}}=12.6 \mathrm{~Hz}\right.$, 6C), $127.4\left(\mathrm{~d}, 3^{\prime} J_{\mathrm{CP}}=16.1 \mathrm{~Hz}\right), 119.8\left(\mathrm{~d}, 1^{\prime} J_{\mathrm{CP}}=86.2 \mathrm{~Hz}, 3 \mathrm{C}\right), 52.0$, $34.6,29.9,29.6,27.9,25.7,23.0\left(\mathrm{~d}, 1^{\prime} J_{\mathrm{CP}}=49.2 \mathrm{~Hz}\right), 21.3\left(\mathrm{~d}, 2^{\prime} J_{\mathrm{CP}}=\right.$ $3.3 \mathrm{~Hz}$ ). HRESITOFMS: $m / z 445.2287[\mathrm{M}]^{+}$(calcd for $\mathrm{C}_{29} \mathrm{H}_{34} \mathrm{O}_{2} \mathrm{P}$, 445.2296); TLC $\left(\mathrm{CH}_{2} \mathrm{Cl}_{2} / \mathrm{MeOH} 95: 5\right) R_{\mathrm{f}}=0.47$.

(R,4E,9Z)-3-((tert-Butyldimethylsilyl)oxy)dodeca-4,9-diene-6-yn1-ol (20). To a solution of vinyl iodide $13(385 \mathrm{mg}, 1.13 \mathrm{mmol}, 1.00$ equiv) in $\mathrm{Et}_{2} \mathrm{NH}(2.50 \mathrm{~mL})$ and benzene $(2.20 \mathrm{~mL})$ was added $\mathrm{Pd}\left(\mathrm{PPh}_{3}\right)_{4}(39.2 \mathrm{mg}, 33.9 \mu \mathrm{mol}, 3.00 \mathrm{~mol} \%)$. The reaction mixture was stirred for $45 \mathrm{~min}$ in the dark before $\mathrm{CuI}(11.2 \mathrm{mg}, 58.8 \mu \mathrm{mol}$, $5.00 \mathrm{~mol} \%$ ) in a minimum amount of $\mathrm{Et}_{2} \mathrm{NH}$ was added followed by dropwise addition of alkyne $10(213 \mathrm{mg})$ in $\mathrm{Et}_{2} \mathrm{NH}(2.20 \mathrm{~mL})$. After stirring for $20 \mathrm{~h}$ at room temperature, the reaction was quenched with a saturated aq solution of $\mathrm{NH}_{4} \mathrm{Cl}(23 \mathrm{~mL})$. The aq phase was extracted with $\mathrm{Et}_{2} \mathrm{O}(3 \times 3.0 \mathrm{~mL})$ before the combined organic layers were dried $\left(\mathrm{Na}_{2} \mathrm{SO}_{4}\right)$ and concentrated in vacuo. The crude product was purified by column chromatography on silica gel (heptane/EtOAc $8: 2$ ) to afford compound 20 as an orange oil. Yield: $299 \mathrm{mg}(86 \%) ;[\alpha]_{D}^{20}+32$ (c 0.40, MeOH); ${ }^{1} \mathrm{H}$ NMR $\left(400 \mathrm{MHz}, \mathrm{CDCl}_{3}\right) \delta_{\mathrm{H}} 6.04(\mathrm{dd}, J=15.8$, $5.7 \mathrm{~Hz}, 1 \mathrm{H}), 5.65(\mathrm{dq}, J=15.8,2.1 \mathrm{~Hz}, 1 \mathrm{H}), 5.51-5.43(\mathrm{~m}, 1 \mathrm{H})$, $5.43-5.34(\mathrm{~m}, 1 \mathrm{H}), 4.43(\mathrm{q}, J=4.9 \mathrm{~Hz}, 1 \mathrm{H}), 3.78(\mathrm{~m}, 1 \mathrm{H}), 3.68(\mathrm{~m}$, $1 \mathrm{H}), 3.05(\mathrm{~d}, J=6.6 \mathrm{~Hz}, 2 \mathrm{H}), 2.27(\mathrm{~s}, 1 \mathrm{H}), 2.12-1.99(\mathrm{~m}, 2 \mathrm{H}), 1.83$ $(\mathrm{m}, 1 \mathrm{H}), 1.69(\mathrm{~m}, 1 \mathrm{H}), 0.98(\mathrm{t}, J=7.5 \mathrm{~Hz}, 3 \mathrm{H}), 0.90(\mathrm{~s}, 9 \mathrm{H}), 0.08(\mathrm{~s}$, $3 \mathrm{H}), 0.05(\mathrm{~s}, 3 \mathrm{H}) ;{ }^{13} \mathrm{C}$ NMR $\left(101 \mathrm{MHz}, \mathrm{CDCl}_{3}\right) \delta_{\mathrm{C}} 144.1,133.7$, 123.4, 110.1, 89.4, 78.2, 72.0, 59.9, 39.4, 25.9, 20.6, 18.2, 17.9, 14.1, -4.3, -4.9; HRESITOFMS: $\mathrm{m} / z$ 331.2063 $[\mathrm{M}+\mathrm{Na}]^{+}$(calcd for $\mathrm{C}_{18} \mathrm{H}_{32} \mathrm{O}_{2} \mathrm{SiNa}, 331.2064$ ); TLC (hexane/EtOAc 7:3, $\mathrm{KMnO}_{4}$ stain) $R_{\mathrm{f}}=0.37$.

(R,4E,9Z)-3-((tert-Butyldimethylsilyl)oxy)dodeca-4,9-dien-6ynal (21). Alcohol 20 ( $240 \mathrm{mg}, 77.9 \mu \mathrm{mol}, 1.00$ equiv) was dissolved in $\mathrm{CH}_{2} \mathrm{Cl}_{2}(23.0 \mathrm{~mL})$ before $\mathrm{NaHCO}_{3}(375 \mathrm{mg}, 4.46 \mathrm{mmol}, 5.70$ equiv) and Dess-Martin periodinane ( $406 \mathrm{mg}, 95.7 \mu \mathrm{mol}, 1.23$ equiv) were added. The reaction mixture was stirred at room temperature for $3 \mathrm{~h}$ before saturated aq $\mathrm{Na}_{2} \mathrm{~S}_{2} \mathrm{O}_{3}(5.0 \mathrm{~mL})$ was added to quench the reaction. The aq phase was extracted with $\mathrm{CH}_{2} \mathrm{Cl}_{2}(2 \times 7.0 \mathrm{~mL})$, and the combined organic layers were dried and concentrated in vacuo. The crude product was purified by column chromatography on silica gel (heptane/EtOAc 8:2) to afford aldehyde 21 as a pale yellow oil. Yield: $219 \mathrm{mg}$ (91\%); $[\alpha]_{D}^{20}+19(c 0.41, \mathrm{MeOH}) ;{ }^{1} \mathrm{H}$ NMR (400 $\left.\mathrm{MHz}, \mathrm{CDCl}_{3}\right) \delta_{\mathrm{H}} 9.75(\mathrm{t}, J=2.3 \mathrm{~Hz}, 1 \mathrm{H}), 6.07(\mathrm{dd}, J=15.8,5.6 \mathrm{~Hz}$, $1 \mathrm{H}), 5.72(\mathrm{dq}, J=15.8,2.1 \mathrm{~Hz}, 1 \mathrm{H}), 5.55-5.34(\mathrm{~m}, 2 \mathrm{H}), 4.68(\mathrm{~m}$, $1 \mathrm{H}), 3.11-3.02(\mathrm{~m}, 2 \mathrm{H}), 2.61$ (ddd, $J=16.0,6.7,2.5 \mathrm{~Hz}, 1 \mathrm{H}), 2.52$ (ddd, $J=16.0,5.1,2.1 \mathrm{~Hz}, 1 \mathrm{H}), 2.07(\mathrm{p}, J=7.3 \mathrm{~Hz}, 2 \mathrm{H}), 0.98(\mathrm{t}, J=$ $7.5 \mathrm{~Hz}, 3 \mathrm{H}), 0.87(\mathrm{~s}, 9 \mathrm{H}), 0.06(\mathrm{~s}, 3 \mathrm{H}), 0.05(\mathrm{~s}, 3 \mathrm{H}) .{ }^{13} \mathrm{C}$ NMR $(101$ $\left.\mathrm{MHz}, \mathrm{CDCl}_{3}\right) \delta_{\mathrm{C}} 201.1,143.1,133.8,123.3,110.7,90.1,77.9,68.6$, 
51.3, 25.9, 20.7, 18.2, 17.9, 14.1, -4.3, -4.9. HRESITOFMS: $\mathrm{m} / \mathrm{z}$ 329.1907 $[\mathrm{M}+\mathrm{Na}]^{+}$(calcd for $\mathrm{C}_{18} \mathrm{H}_{30} \mathrm{O}_{2} \mathrm{SiNa}$, 329.1913); TLC (hexane/EtOAc 85:15, $\mathrm{KMnO}_{4}$ stain) $R_{\mathrm{f}}=0.38$.

Methyl-(R,7Z,10Z,14E,19Z)-13-((tert-butyldimethylsilyl)oxy)docosa-7, 10,14,19-tetraen-16-ynoate (22). Wittig salt $19(374 \mathrm{mg}$, $65.4 \mu \mathrm{mol}, 1.00$ equiv) was dissolved in THF $(8.80 \mathrm{~mL})$ and HMPA $(0.88 \mathrm{~mL})$, cooled to $-78{ }^{\circ} \mathrm{C}$ and added NaHMDS (0.6 M in toluene, $1.09 \mathrm{~mL}, 65.4 \mu \mathrm{mol}, 1.00$ equiv). The reaction mixture was stirred for $45 \mathrm{~min}$ before aldehyde 21 (200 mg, $65.5 \mu \mathrm{mol}, 1.00$ equiv) in THF $(0.88 \mathrm{~mL})$ was added dropwise. The reaction was stirred for $1 \mathrm{~h}$ at $-78{ }^{\circ} \mathrm{C}$ and then the reaction mixture was allowed to slowly warm to $0{ }^{\circ} \mathrm{C}$. Phosphate buffer $(4.7 \mathrm{~mL}, \mathrm{pH}=7.2)$ was added to quench the reaction and the aq. phase was extracted with $\mathrm{Et}_{2} \mathrm{O}(2 \times 4.0 \mathrm{~mL})$. The combined organic layers were dried $\left(\mathrm{Na}_{2} \mathrm{SO}_{4}\right)$ and concentrated in vacuo. The crude product was purified by column chromatography on silica gel (heptane/EtOAc 95:5, $\mathrm{KMnO}_{4}$ stain) to afford compound 22 as a pale yellow oil. Yield: $239 \mathrm{mg}(77 \%) ;[\alpha]_{D}^{20}+2.1\left(c 0.39, \mathrm{CHCl}_{3}\right)$; ${ }^{1} \mathrm{H}$ NMR $\left(400 \mathrm{MHz}, \mathrm{MeOH}-d_{4}\right) \delta_{\mathrm{H}} 5.98(\mathrm{dd}, J=15.8,5.8 \mathrm{~Hz}, 1 \mathrm{H})$, $5.62(\mathrm{dq}, J=15.8,2.0 \mathrm{~Hz}, 1 \mathrm{H}), 5.51-5.29(\mathrm{~m}, 6 \mathrm{H}), 4.22(\mathrm{q}, J=5.6$ $\mathrm{Hz}, 1 \mathrm{H}), 3.65(\mathrm{~s}, 3 \mathrm{H}), 3.05(\mathrm{~d}, J=6.7 \mathrm{~Hz}, 2 \mathrm{H}), 2.78(\mathrm{q}, J=5.9 \mathrm{~Hz}$, $2 \mathrm{H}), 2.32(\mathrm{t}, J=7.4 \mathrm{~Hz}, 2 \mathrm{H}), 2.27(\mathrm{q}, J=6.9 \mathrm{~Hz}, 2 \mathrm{H}), 2.08(\mathrm{q}, J=7.0$ $\mathrm{Hz}, 4 \mathrm{H}), 1.62(\mathrm{p}, J=7.5 \mathrm{~Hz}, 2 \mathrm{H}), 1.45-1.28(\mathrm{~m}, 4 \mathrm{H}), 0.99(\mathrm{t}, J=7.5$ $\mathrm{Hz}, 3 \mathrm{H}), 0.91(\mathrm{~s}, 9 \mathrm{H}), 0.07(\mathrm{~s}, 3 \mathrm{H}), 0.05(\mathrm{~s}, 3 \mathrm{H}) ;{ }^{13} \mathrm{C}$ NMR $(101$ $\left.\mathrm{MHz}, \mathrm{MeOH}-d_{4}\right) \delta_{\mathrm{C}} 175.9,145.6,134.2,131.3,130.9,129.0,126.2$, $124.8,110.8,89.7,79.1,74.0,52.0,37.1,34.8,30.4,29.8,28.1,26.8$, 26.40 (3C), 25.9, 21.4, 19.1, 18.2, 14.4, $-4.3,-4.5$; HRESITOFMS: $m / z$ 495.3265 $[\mathrm{M}+\mathrm{Na}]^{+}$(calcd for $\mathrm{C}_{29} \mathrm{H}_{48} \mathrm{O}_{3} \mathrm{SiNa}, 495.3270$ ); TLC (hexane/EtOAc 85:15, $\mathrm{KMnO}_{4}$ stain) $R_{\mathrm{f}}=0.47$.

Methyl-(R,7Z,10Z,14E,19Z)-13-hydroxydocosa-7, 10,14,19-tetraen-16-ynoate (23). The TBS-protected intermediate $22(64.1 \mathrm{mg}$, $0.136 \mathrm{mmol}, 1.00$ equiv) was twice azeotroped with 2-Me-THF and then stirred under argon at $0{ }^{\circ} \mathrm{C}$ before a solution of $\mathrm{AcCl}$ in dry $\mathrm{MeOH}(1.00 \mathrm{~mL}, 20.4 \mu \mathrm{mol}, 15.0 \mathrm{~mol} \%)$ was added. The solution of $\mathrm{AcCl}$ in $\mathrm{MeOH}$ was prepared just prior to use by adding $\mathrm{AcCl}$ (3.0 $\mu \mathrm{L})$ to dry $\mathrm{MeOH}(2.0 \mathrm{~mL})$ under argon. The reaction mixture was stirred for $7 \mathrm{~h}$ at $0{ }^{\circ} \mathrm{C}$. Then $\mathrm{CH}_{2} \mathrm{Cl}_{2}(2.7 \mathrm{~mL})$ was added, and the reaction was neutralized with a $10 \%$ aq solution of $\mathrm{NaHCO}_{3}(140 \mu \mathrm{L})$ and washed with $\mathrm{H}_{2} \mathrm{O}(1.4 \mathrm{~mL})$. The combined organic layers were dried $\left(\mathrm{Na}_{2} \mathrm{SO}_{4}\right)$, and the solvent was removed in vacuo, before the crude product was purified by column chromatography on silica gel (heptane/EtOAc 85:15) to afford the alcohol 23 as a clear oil. Yield: $44.7 \mathrm{mg}(92 \%) ;[\alpha]_{D}^{20}=-9.0(c=0.27, \mathrm{MeOH}) ; \mathrm{UV}(\mathrm{MeOH}) \lambda_{\max }$ 229, $(\log \varepsilon 3.97) ;{ }^{1} \mathrm{H}$ NMR $\left(400 \mathrm{MHz}, \mathrm{MeOH}-d_{4}\right) \delta_{\mathrm{H}} 6.01(\mathrm{dd}, J=$ $15.9,6.1 \mathrm{~Hz}, 1 \mathrm{H}), 5.66(\mathrm{dq}, J=15.9,2.2 \mathrm{~Hz}, 2 \mathrm{H}), 5.52-5.32(\mathrm{~m}, 6 \mathrm{H})$, $4.11(\mathrm{dq}, \mathrm{J}=6.4,1.0 \mathrm{~Hz}, 1 \mathrm{H}), 3.67(\mathrm{~s}, 3 \mathrm{H}), 3.06(\mathrm{~d}, J=6.8 \mathrm{~Hz}, 2 \mathrm{H})$, $2.81(\mathrm{~m}, 2 \mathrm{H}), 2.38-2.27(\mathrm{~m}, 4 \mathrm{H}), 2.15-2.05(\mathrm{~m}, 4 \mathrm{H}), 1.64(\mathrm{p}, J=7.4$ $\mathrm{Hz}, 2 \mathrm{H}), 1.47-1.29(\mathrm{~m}, 4 \mathrm{H}), 1.00(\mathrm{t}, J=7.5 \mathrm{~Hz}, 3 \mathrm{H}) .{ }^{13} \mathrm{C}$ NMR $(101$ $\left.\mathrm{MHz}, \mathrm{MeOH}-d_{4}\right) \delta_{\mathrm{C}} 176.0,145.2,134.2,131.4,131.0,128.9,126.0$, $124.8,111.2,89.6,79.1,72.7,52.0,36.1,34.8,30.4,29.8,28.0,26.8$, 25.9, 21.4, 18.2, 14.3; HRESITOFMS: $m / z 381.2400[\mathrm{M}+\mathrm{Na}]^{+}(\mathrm{calcd}$ for $\mathrm{C}_{23} \mathrm{H}_{34} \mathrm{O}_{3} \mathrm{Na}$, 381.2406); TLC (hexane/EtOAc 80:20, $\mathrm{KMnO}_{4}$ stain) $R_{\mathrm{f}}=0.36$. The chemical purity $(>98 \%)$ was determined by HPLC analysis (Eclipse XDB-C18, $\mathrm{MeOH} / \mathrm{H}_{2} \mathrm{O} 85: 15,1.0 \mathrm{~mL} / \mathrm{min}$ ): $t_{\mathrm{r}}($ major $)=12.94$ min and $t_{\mathrm{r}}($ minor $)=15.74 \mathrm{~min}$.

Methyl $(R, 7 Z, 10 Z, 14 E, 16 Z, 19 Z)-13$-hydroxydocosa-7,10,14,16,19pentaenoate (24). The activated $\mathrm{Zn}$ was prepared according to the literature. ${ }^{16}$ A suspension of $\mathrm{Zn}$ dust $(2.04 \mathrm{~g})$ in distilled $\mathrm{H}_{2} \mathrm{O}(12.3$ $\mathrm{mL})$ was stirred under argon for $15 \mathrm{~min} . \mathrm{Cu}(\mathrm{OAc})_{2} \cdot \mathrm{H}_{2} \mathrm{O}(204 \mathrm{mg}$, $1.02 \mathrm{mmol}$ ) was added, the flask was sealed immediately, and the mixture stirred vigorously for $15 \mathrm{~min}$. Then $\mathrm{AgNO}_{3}$ (204 mg, 1.2 mmol) was added (exothermic reaction), and the reaction mixture was stirred for an additional $30 \mathrm{~min}$. The activated $\mathrm{Zn}$ was filtered under argon atmosphere and washed successively with $\mathrm{H}_{2} \mathrm{O}, \mathrm{MeOH}$, acetone, and $\mathrm{Et}_{2} \mathrm{O}$ to give a wet material (the activated $\mathrm{Zn}$ was not dried completely). Alkyne 23 ( $30 \mathrm{mg}, 83.7 \mu \mathrm{mol})$ was dissolved in $\mathrm{MeOH} / \mathrm{H}_{2} \mathrm{O}(2: 1)(6.00 \mathrm{~mL})$, and then the wet activated $\mathrm{Zn}$ was added quickly under a blanket of argon. The reaction was stirred for 10 $\mathrm{h}$ in the dark. After completion, the mixture was filtered through Celite with $\mathrm{Et}_{2} \mathrm{O}$, and the aq phase was extracted with EtOAc $(3 \times 3.0 \mathrm{~mL})$. The organic layers were dried $\left(\mathrm{Na}_{2} \mathrm{SO}_{4}\right)$ and the solvent removed in vacuo, before the crude product was purified by column chromatography on silica gel (heptane/EtOAc 90:10) to afford the methyl ester 24 as a clear oil. Yield $20.2 \mathrm{mg}(67 \%):[\alpha]_{D}^{20}-0.5(c=0.74, \mathrm{MeOH})$; $\mathrm{UV}(\mathrm{MeOH}) \lambda_{\max } 237,(\log \varepsilon=4.41) ;{ }^{1} \mathrm{H}$ NMR $(400 \mathrm{MHz}, \mathrm{MeOH}-$ $\left.d_{4}\right) \delta_{\mathrm{H}} 6.55(\mathrm{ddt}, J=15.1,11.0,1.1 \mathrm{~Hz}, 1 \mathrm{H}), 5.97(\mathrm{t}, J=10.9 \mathrm{~Hz}, 1 \mathrm{H})$, $5.68(\mathrm{dd}, J=15.2,6.5 \mathrm{~Hz}, 1 \mathrm{H}), 5.50-5.26(\mathrm{~m}, 7 \mathrm{H}), 4.15(\mathrm{q}, J=6.5$ $\mathrm{Hz}, 1 \mathrm{H}), 3.65(\mathrm{~s}, 3 \mathrm{H}), 2.94(\mathrm{t}, J=7.2 \mathrm{~Hz}, 2 \mathrm{H}), 2.80(\mathrm{t}, J=5.5 \mathrm{~Hz}$, $2 \mathrm{H}), 2.43-2.21(\mathrm{~m}, 4 \mathrm{H}), 2.18-2.02(\mathrm{~m}, 4 \mathrm{H}), 1.61(\mathrm{p}, J=7.4 \mathrm{~Hz}$, $2 \mathrm{H}), 1.46-1.26(\mathrm{~m}, 4 \mathrm{H}), 0.98(\mathrm{t}, J=7.5 \mathrm{~Hz}, 3 \mathrm{H}) ;{ }^{13} \mathrm{C}$ NMR $(101$ $\left.\mathrm{MHz}, \mathrm{MeOH}-d_{4}\right) \delta_{\mathrm{C}} 176.0,137.2,133.1,131.2,131.0,130.9,129.2$, 129.0, 127.8, 126.4, 126.4, 73.1, 52.0, 36.4, 34.8, 30.4, 29.8, 28.0, 26.9 26.8, 25.9, 21.5, 14.6; HRESITOFMS: $m / z 383.2555[\mathrm{M}+\mathrm{Na}]^{+}$ (calcd for $\mathrm{C}_{23} \mathrm{H}_{36} \mathrm{O}_{3} \mathrm{Na}$, 383.2562); TLC (hexane/EtOAc 75:25, $\mathrm{KMnO}_{4}$ stain) $R_{\mathrm{f}}=0.33$. The chemical purity $(>98 \%)$ was determined by HPLC analysis (Eclipse XDB-C18, $\mathrm{MeOH} / \mathrm{H}_{2} \mathrm{O} 85: 15,1.0 \mathrm{~mL}$ / $\min ): t_{\mathrm{r}}($ minor $)=13.72$ and $17.53 \mathrm{~min}$, and $t_{\mathrm{r}}($ major $)=16.53 \mathrm{~min}$.

$(R, 7 Z, 10 Z, 14 E, 16 Z, 19 Z)$-13-Hydroxydocosa-7, 10,14,16,19-pentaenoic Acid, 13R-HDPA (5). Methyl ester $24(12.0 \mathrm{mg}, 33.3 \mu \mathrm{mol}$, 1.00 equiv) was dissolved in $\mathrm{THF} / \mathrm{MeOH} / \mathrm{H}_{2} \mathrm{O}(2: 2: 1,3.90 \mathrm{~mL})$ and cooled to $0{ }^{\circ} \mathrm{C}$. $\mathrm{LiOH}(24 \mathrm{mg}, \mathrm{mmol}, 30.0$ equiv) was added in one portion. The reaction mixture was stirred for $3 \mathrm{~h}$ at $0{ }^{\circ} \mathrm{C}$ before it was allowed to warm up to room temperature and stirred until completion, as monitored by TLC $(\sim 2 \mathrm{~h})$. Saturated aq $\mathrm{NaH}_{2} \mathrm{PO}_{4}(6.0 \mathrm{~mL})$ was added. The aq phase was extracted $(2 \times 3.0 \mathrm{~mL})$, dried $\left(\mathrm{Na}_{2} \mathrm{SO}_{4}\right)$, and the solvent was removed in vacuo. The crude product was purified by column chromatography on silica gel (heptane/EtOAc 50:50, $\mathrm{KMnO}_{4}$ stain) to afford the hydroxy acid 5 as colorless oil. Yield: $10.0 \mathrm{mg}$ $(87 \%) ;[\alpha]_{D}^{25}-0.64(c=0.47, \mathrm{MeOH}) ; \mathrm{UV}(\mathrm{MeOH}) \lambda_{\max } 236,(\log \varepsilon=$ 4.39); ${ }^{1} \mathrm{H}$ NMR $\left(400 \mathrm{MHz}, \mathrm{MeOH}-d_{4}\right) \delta_{\mathrm{H}} 6.55$ (ddt, $J=15.2,11.1$, $1.2 \mathrm{~Hz}, 1 \mathrm{H}), 5.97(\mathrm{t}, J=10.9 \mathrm{~Hz}, 1 \mathrm{H}), 5.68(\mathrm{dd}, J=15.2,6.5 \mathrm{~Hz}, 1 \mathrm{H})$, $5.49-5.26(\mathrm{~m}, 7 \mathrm{H}), 4.15(\mathrm{q}, J=6.5 \mathrm{~Hz}, 1 \mathrm{H}), 2.94(\mathrm{t}, J=7.2 \mathrm{~Hz}, 2 \mathrm{H})$, $2.80(\mathrm{t}, J=5.8 \mathrm{~Hz}, 2 \mathrm{H}), 2.40-2.22(\mathrm{~m}, 4 \mathrm{H}), 2.09(\mathrm{q}, J=7.6,6.9 \mathrm{~Hz}$, $4 \mathrm{H}), 1.61(\mathrm{p}, J=7.4 \mathrm{~Hz}, 2 \mathrm{H}), 1.38(\mathrm{~m}, 4 \mathrm{H}), 0.98(\mathrm{t}, J=7.5 \mathrm{~Hz}, 3 \mathrm{H})$; ${ }^{13} \mathrm{C}$ NMR $(101 \mathrm{MHz}, \mathrm{MeOH}-d 4) \delta_{\mathrm{C}} 177.7,137.1,133.1,131.2,131.1$, $130.9,129.2,129.0,127.8,126.4,126.4,73.1,36.4,35.0,30.4,29.9$, 28.1, 26.9, 26.8, 26.0, 21.5, 14.6; HRESITOFMS: $m / z$ 369.2400 [M + $\mathrm{Na}]^{+}$(calcd for $\mathrm{C}_{22} \mathrm{H}_{34} \mathrm{O}_{3} \mathrm{Na}, 369.2406$ ); TLC (hexane/EtOAc 50:50, $\mathrm{KMnO}_{4}$ stain) $R_{\mathrm{f}}=0.27$.

Biogenic 13R-HDPA. Human umbilical vein endothelial cells (HUVEC; $8.5 \times 10^{5}$ cells $\left./ 9.6 \mathrm{~cm}^{2}\right)$ were incubated with IL-1 $\beta$ (10 $\mathrm{ng} / \mathrm{mL})$ and TNF- $\alpha\left(10 \mathrm{ng} / \mathrm{mL} ; 16 \mathrm{~h}, 37^{\circ} \mathrm{C}, 5 \% \mathrm{CO}_{2}\right)$. Incubations were quenched using 2 volumes of $\mathrm{MeOH}$ containing deuterium labeled $d_{8}$-5S-HETE.

In separate experiments n-3 DPA (Cayman Chemical Company) was incubated with human recombinant COX-2 (Cayman Chemicals; in $0.1 \mathrm{M}$ Tris- $\mathrm{HCl}, \mathrm{pH} 8.0,20 \mu \mathrm{M}$ porcine hematin, $0.67 \mathrm{mM}$ phenol) for $30 \mathrm{~min}$ at room temperature. Incubations were stopped with two volumes of $\mathrm{MeOH}$ and products extracted using diethyl ether. ${ }^{8}$ 13HDPA was isolated using RP-HPLC (1260 Series; Agilent Technologies $)$ and an Agilent C18 Poroshell column $(3.5 \mu \mathrm{m} \times 4.6$ $\mathrm{mm} \times 150 \mathrm{~mm})$ with a mobile phase consisting of $\mathrm{MeOH} / \mathrm{H}_{2} \mathrm{O}$ $(60: 40, \mathrm{vol} / \mathrm{vol})$ at $0.5 \mathrm{~mL} / \mathrm{min}$ that was ramped up to $98: 2(\mathrm{v} / \mathrm{v})$ for $20 \mathrm{~min}$.

Infectious exudates were collected from mice (6-8 week old, male, FvB, Charles River, UK) $12 \mathrm{~h}$ after administration of E. coli $\left(10^{5}\right.$ $\mathrm{CFU}$ ). ${ }^{28}$ Exudates were collected in $4 \mathrm{~mL}$ of PBS (containing calcium and magnesium) and placed in 2 volumes of ice-cold $\mathrm{MeOH}$ containing $d_{8}$-5S-HETE and commercially available lipid mediators. In these experiments, male FvB mice (6-8 weeks of age) were used. These animals were maintained on a standard chow pellet diet and had access to water ad libitum, with a 12-h light-dark cycle. All animal experiments were approved and performed under the guidelines of the Ethical Committee for the Use of Animals, Barts and The London School of Medicine, and in accordance with the U.K. Home Office regulations (Guidance on the Operation of Animals, Scientific Procedures Act, 1986).

RvT Biosynthesis. Human peripheral blood was collected according to a protocol approved by Barts and the London Research Ethics Committee, London, United Kingdom (QMREC 2014:61). Written informed consent was received from participants prior to inclusion in 
the study according to the Declaration of Helsinki. Neutrophils were prepared following density separation by layering on Ficoll-Histopaque $1077-1$. The cells were then centrifuged at $300 \mathrm{~g}\left(30 \mathrm{~min}, 4{ }^{\circ} \mathrm{C}\right)$, and contaminating red blood cells were lysed by hypotonic lyses as in ref 8 . Neutrophils $20 \times 10^{6}$ cells $/ \mathrm{mL}\left(\mathrm{PBS}^{+/+}, \mathrm{pH}=7.45\right)$ were then incubated with synthetic $13 R$-HDPA $(5)(10 \mu \mathrm{M})$ for $45 \min \left(37^{\circ} \mathrm{C}\right)$. Incubations were stopped with 2 volumes of ice-cold $\mathrm{MeOH}$. $\mathrm{NaBH}_{4}$ was then added to reduce the hydroperoxides produced by the neutrophil lipoxygenases $(1.0 \mathrm{mg} / \mathrm{mL}$; Sigma-Aldrich), and products were isolated using C18 solid phase extraction as detailed below.

Lipid Mediator Profiling. $\mathrm{MeOH}$ (two volumes) was added to cell incubations, plasma (mouse and human), and infectious exudates, and samples were stored at $-20{ }^{\circ} \mathrm{C}$ until extraction. Prior to extraction, samples were then centrifuged $\left(1200 \mathrm{~g}, 4^{\circ} \mathrm{C}, 10 \mathrm{~min}\right)$. Supernatants were then collected and brought to less than $1.0 \mathrm{~mL}$ of $\mathrm{MeOH}$ content using a gentle stream of nitrogen gas using a TurboVap LV system (Biotage). The RvT1-4 and 13-HDPA products were extracted using an ExtraHera (Biotage) automated extraction system as follows. Solidphase $\mathrm{C} 18$ cartridges were equilibrated with $3.0 \mathrm{~mL}$ of $\mathrm{MeOH}$ and 6.0 $\mathrm{mL}$ of $\mathrm{H}_{2} \mathrm{O}$. Nine milliliters of aq $\mathrm{HCl}$ solution $(\mathrm{pH}=3.5)$ was then added to the samples, and the acidified solutions were rapidly loaded onto the conditioned $\mathrm{C} 18$ columns that were washed with $4.0 \mathrm{~mL}$ of $\mathrm{H}_{2} \mathrm{O}$. Next, $5.0 \mathrm{~mL}$ of hexane was added, and the products were eluted with $4.0 \mathrm{~mL}$ of methyl formate. Products were brought to dryness using the automated evaporation system (TurboVap LV, Biotage) and immediately suspended in $\mathrm{MeOH}-\mathrm{H}_{2} \mathrm{O}$ (50:50 vol/vol) for LC-MSMS automated injections as previously reported. ${ }^{8}$

Extracted samples were analyzed by an LC-MS-MS system, Qtrap 5500 (AB Sciex) equipped with a Shimadzu SIL-20AC autoinjector and LC-20AD binary pump (Shimadzu Corp.). A Poroshell C18 column $(100 \mathrm{~mm} \times 4.6 \mathrm{~mm} \times 2.7 \mu \mathrm{m})$ was used with a gradient of $\mathrm{MeOH} / \mathrm{H}_{2} \mathrm{O} / \mathrm{AcOH}$ of $55: 45: 0.01(\mathrm{v} / \mathrm{v} / \mathrm{v})$ that was ramped to 85:15:0.01 (v/v/v) over $10 \mathrm{~min}$ and then to $98: 2: 0.01(\mathrm{v} / \mathrm{v} / \mathrm{v})$ for the next $8 \mathrm{~min}$. This was subsequently maintained at 98:2:0.01 (v/v/v) for $2 \mathrm{~min}$. The flow rate was maintained at $0.4 \mathrm{~mL}$ per minute.

To monitor and quantify the levels of lipid mediators, a multiple reaction monitoring (MRM) method was developed with signature ion fragments $(\mathrm{m} / \mathrm{z})$ for each molecule monitoring the parent ion (Q1) and a characteristic daughter ion (Q3). Identification was conducted using published criteria where a minimum of 6 diagnostic ions were employed, see ref 18 for details. Detection limit was $\sim 0.1 \mathrm{pg}$.

For chiral-phase lipidomic analysis, a Chiralpak $\mathrm{AD}-\mathrm{RH}$ column $(150 \mathrm{~mm} \times 2.1 \mathrm{~mm} \times 5 \mu \mathrm{m})$ was used with isocratic $\mathrm{MeOH} / \mathrm{H}_{2} \mathrm{O} /$ $\mathrm{AcOH}$ 95:5:0.01 (v/v/v) at $0.15 \mathrm{~mL} / \mathrm{min}$. To monitor isobaric monohydroxy docosapentaenoic acid levels, a multiple reaction monitoring (MRM) method was developed using signature ion fragments $345>195$ described. $^{8}$

\section{ASSOCIATED CONTENT}

\section{S Supporting Information}

The Supporting Information is available free of charge on the ACS Publications website at DOI: 10.1021/acs.jnatprod.6b00634.

${ }^{1} \mathrm{H},{ }^{13} \mathrm{C}$ spectral data, HRMS and UV-vis spectra, as well as chromatograms from HPLC analyses of synthetic intermediates and 13R-HDPA (5) (PDF)

\section{AUTHOR INFORMATION}

\section{Corresponding Authors}

*E-mail: j.dalli@qmul.ac.uk.

*E-mail: t.v.hansen@farmasi.uio.no.

*E-mail: anders.vik@farmasi.uio.no.

\section{Author Contributions}

The manuscript was written through contributions of all authors. All authors have given approval to the final version of the manuscript.

\section{Notes}

The authors declare the following competing financial interest(s): J. D. and C. N. S. have filed patents on RvT1 (1), RvT2 (2), RvT3 (3), RvT4 (4), 13R-HDPA (5) and related compounds. C. N. S.s interests are reviewed and are managed by BWH and Partners HealthCare in accordance with their conflict of interest policies.

$\S$ (K.G.P.) On leave from the School of Pharmacy, Department of Pharmaceutical Chemistry, University of Oslo.

\section{ACKNOWLEDGMENTS}

The Norwegian Research Council is gratefully acknowledged for funding to T.V.H and a postdoctoral fellowship to M.A. (FRIPRO-FRINATEK 230470). We are thankful to the School of Pharmacy, University of Oslo, for a Ph.D. scholarship to K.G.P. and for the generous support from the Norwegian Ph.D. School of Pharmacy (Nasjonal forskerskole i farmasi, NFIF) for a travel grant. J.D. is supported by a Sir Henry Dale Fellowship jointly funded by the Wellcome Trust and the Royal Society (Grant number $107613 / \mathrm{Z} / 15 / \mathrm{Z}$ ). C.N.S. is supported by the National Institutes of Health GM Grant PO1GM095467.

\section{REFERENCES}

(1) Serhan, C. N.; Dalli, J.; Colas, R. A.; Winkler, J. W.; Chiang, N. Biochim. Biophys. Acta, Mol. Cell Biol. Lipids 2015, 1851, 397-413.

(2) (a) Dalli, J.; Chiang, N.; Serhan, C. N. Proc. Natl. Acad. Sci. U. S. A. 2014, 111, E4753-E4761. (b) Dalli, J.; Ramon, S.; Norris, P. C.; Colas, R. A.; Serhan, C. N. FASEB J. 2015, 29, 2120-2136. (c) Ramon, S.; Dalli, J.; Sanger, J. M.; Winkler, J. W.; Aursnes, M.; Tungen, J. E.; Hansen, T. V.; Serhan, C. N. Am. J. Pathol. 2016, 186, 962-973.

(3) Sugimoto, M. A.; Sousa, L. P.; Pinho, V.; Perretti, M.; Teixeira, M. M. Front. Immunol. 2016, 7, 160.

(4) Tabas, I.; Glass, C. K. Science 2013, 339, 166-172.

(5) Serhan, C. N.; Petasis, N. A. Chem. Rev. 2011, 111, 5922-5943 and references cited therein.

(6) Dalli, J.; Colas, R. A.; Serhan, C. N. Sci. Rep. 2013, 3, 1940.

(7) Aursnes, M.; Tungen, J. E.; Vik, A.; Colas, R.; Cheng, C.-Y.; Dalli, J.; Serhan, C. N.; Hansen, T. V. J. Nat. Prod. 2014, 77, 910-916.

(8) Dalli, J.; Chiang, N.; Serhan, C. N. Nat. Med. 2015, 21, 10711075.

(9) Serhan, C. N. Biochim. Biophys. Acta, Lipids Lipid Metab. 1994, $1212,1-25$

(10) (a) Neu, H. C. Science 1992, 257, 1064-1073. (b) Ward, P. A. EMBO Mol. Med. 2012, 4, 1234-1243.

(11) Mowat, J.; Senior, J.; Kang, B.; Britton, R. Can. J. Chem. 2013, 91, 235-239.

(12) Brown, C. A.; Ahuja, V. K. J. Chem. Soc., Chem. Commun. 1973, 553-554.

(13) Hansen, T. V.; Stenstrøm, Y. Tetrahedron: Asymmetry 2001, 12, 1407-1409.

(14) Tungen, J. E.; Aursnes, M.; Dalli, J.; Arnardottir, H.; Serhan, C. N.; Hansen, T. V. Chem. - Eur. J. 2014, 20, 14575-14578.

(15) Khan, A. T.; Mondal, E. Synlett 2003, 694-698.

(16) Boland, W.; Schroer, N. C.; Sieler, C. M.; Feigel, M. Helv. Chim. Acta 1987, 70, 1025-1040.

(17) Aursnes, M.; Tungen, J. T.; Vik, A.; Dalli, J.; Hansen, T. V. Org. Biomol. Chem. 2014, 12, 432-437.

(18) Colas, R. A.; Shinohara, M.; Dalli, J.; Chiang, N.; Serhan, C. N. Am. J. Physiol. Cell. Physiol. 2014, 307, C39-54.

(19) Haeggström, J. Z.; Funk, C. C. Chem. Rev. 2011, 111, 58665898.

(20) Brezinski, M. E.; Serhan, C. N. Proc. Natl. Acad. Sci. U. S. A. 1990, 87, 6248-6252.

(21) Gerwick, W. H. Chem. Rev. 1993, 93, 1807-1823.

(22) Serhan, C. N. Nature 2014, 510, 92-101. 
(23) (a) Samuelsson, B. J. Biol. Chem. 2012, 287, 10070-10080.

(b) Barbosa, M.; Valentão; Andrade, P. B. Mar. Drugs 2016, 14, 23.

(c) Basil, M. C.; Levy, B. D. Nat. Rev. Immunol. 2016, 16, 51-67.

(24) Trost, B. M.; Pinkerton, A. B. J. Org. Chem. 2001, 66, 77147722.

(25) Billington, D. C.; Bladon, P.; Helps, M.; Pauson, P. L.; Thomson, W.; Willison, D. J. Chem. Res., Synop. 1988, 2601-2609.

(26) Huang, Z.; Negishi, E.-I. Org. Lett. 2006, 8, 3675-3678.

(27) Lucet, D.; Heyse, P.; Gissot, A.; Le Gall, T.; Mioskowski, C. Eur. J. Org. Chem. 2000, 2000 (21), 3575-3579.

(28) Chiang, N.; Fredman, G.; Backhed, F.; Oh, S. F.; Vickery, T.; Schmidt, B. A.; Serhan, C. N. Nature 2012, 484, 524-529. 